\begin{tabular}{|c|c|}
\hline AUG 121996 21 ENGINEERING DATA TRANSMITTAL & Page 1 of $\frac{1}{1 . \text { EOT NO } 614551}$ \\
\hline
\end{tabular}

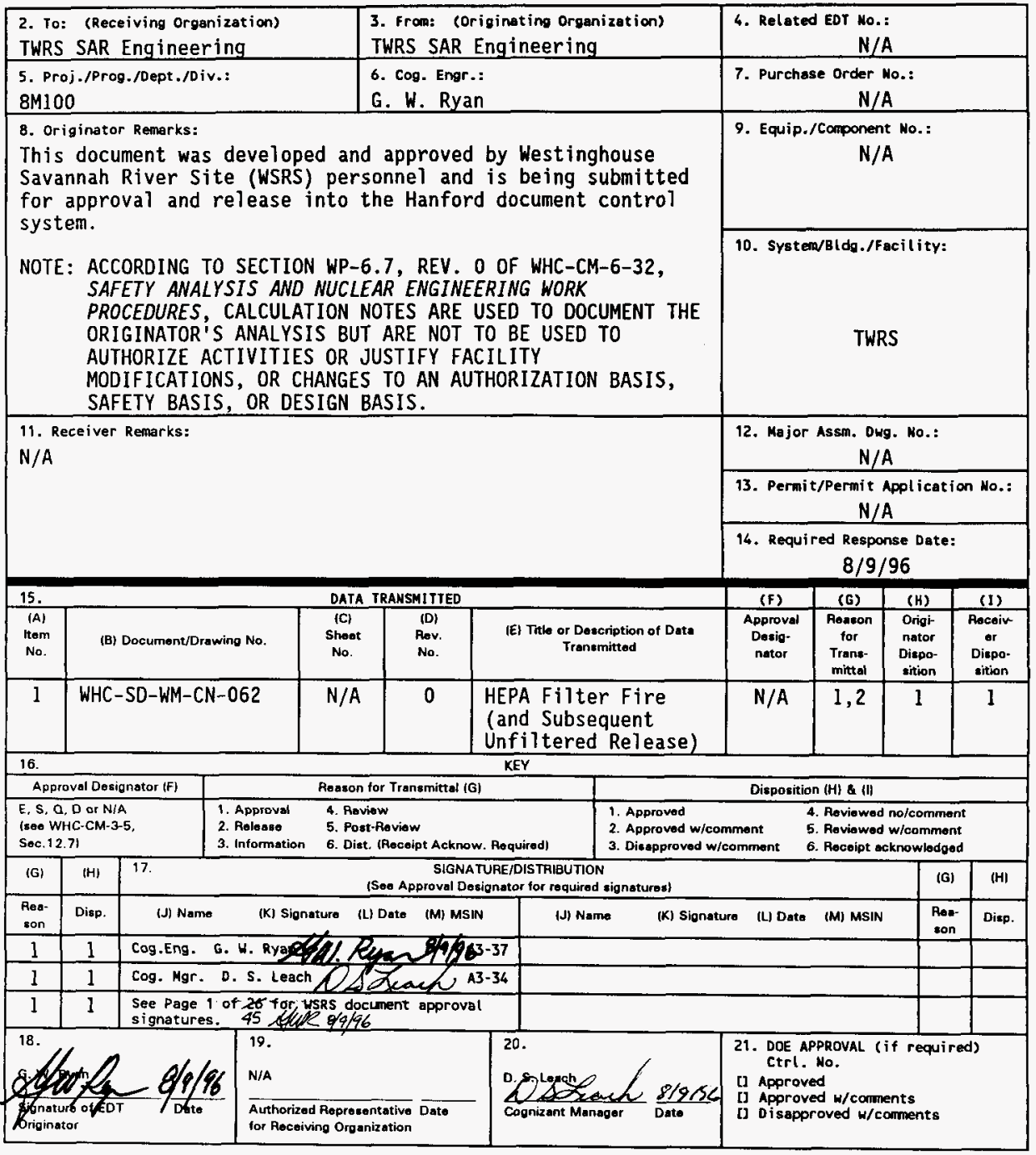

BD-7400-172-2 (04/94) GEF097 


\section{HEPA Filter Fire (and Subsequent Unfiltered Release)}

G. W. Ryan

Westinghouse Hanford Company, Richland, WA 99352

U.S. Department of Energy Contract DE-AC06-87RL10930

\begin{tabular}{|c|c|c|}
\hline $\begin{array}{l}\text { EOT/ECN: } \\
\text { Org Code: } \\
\text { B\&R Code: }\end{array}$ & $\begin{array}{l}614551 \\
8 M 100 \\
\text { EW3120071 }\end{array}$ & $\begin{array}{l}\text { UC: } 510 \\
\text { Charge Code: } \\
\text { Total Pages: }\end{array}$ \\
\hline
\end{tabular}

Key Words: contaminated fire, fire, HEPA filter fire, radioactive materials, TWRS, tank farms, ventilation system

Abstract: This document supports the development and presentation of the following accident scenario in the TWRS Final Safety Analysis Report:

\section{HEPA Filter Failure - Exposure to High Temperature or Pressure.}

The calculations needed to quantify the risk associated with this accident scenario are included within.

TRADEMARK DISCLAIMER. Reference herein to any specific comercial product, process, or service by trade name, trademark, manufacturer, or otherwise, does not necessarily constitute or imply its endorsement, recommendation, or favoring by the United States Government or any agency thereof or its contractors or subcontractors.

Printed in the United States of America. To obtain copies of this document, contact: WHC/BCS Document Control Services, P.O. Box 1970, Mailstop H6-08, Richland WA 99352, Phone (509) 372-2420; Fax (509) $376-4989$.
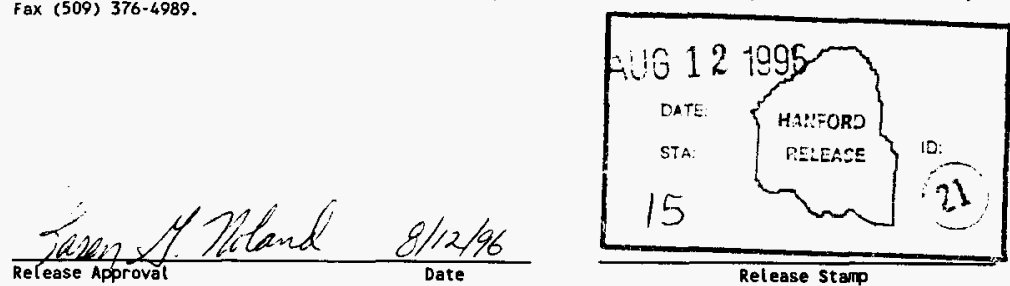

Approved for Public Release 


\section{Calculation Cover Sheet}

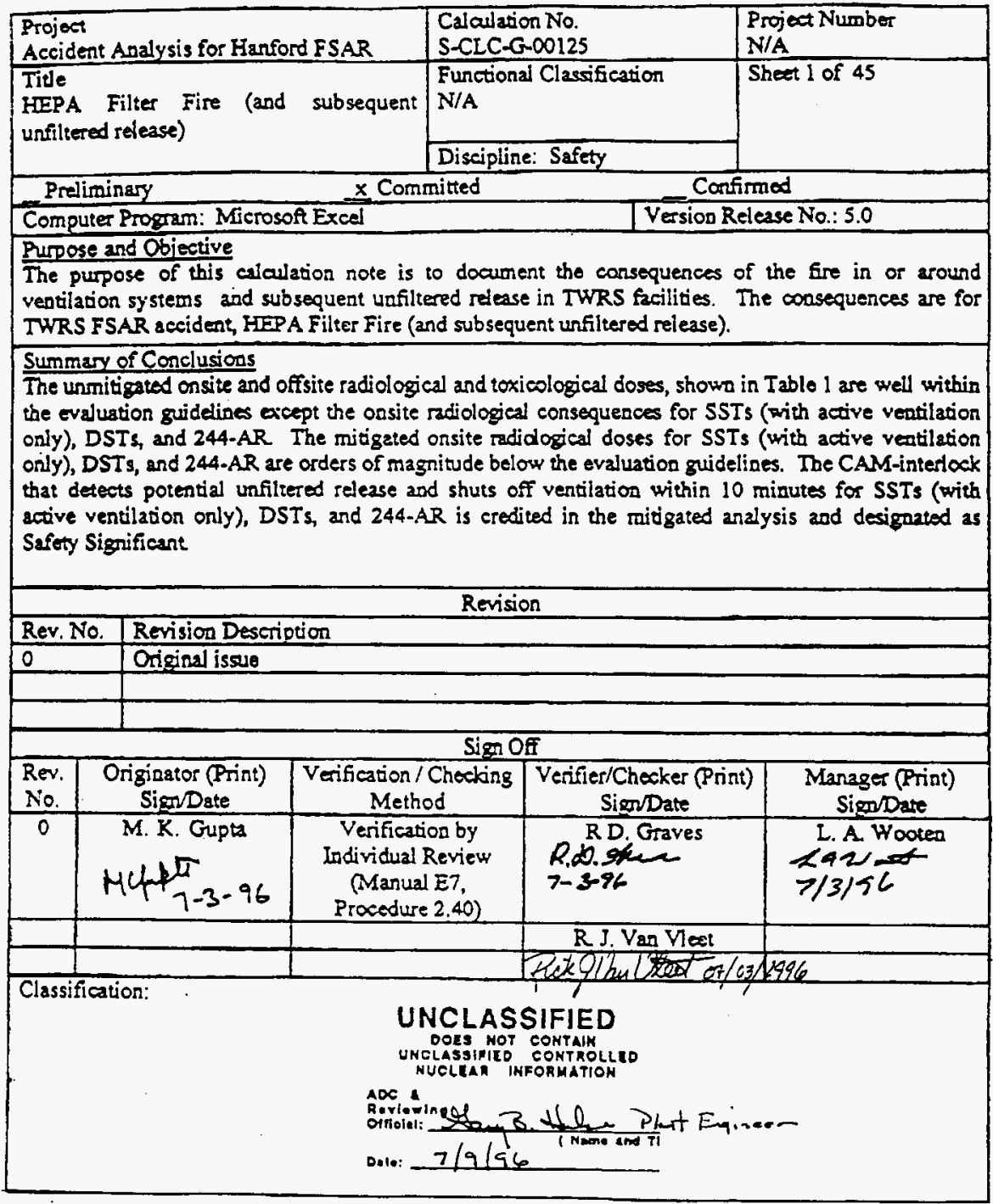




\section{TABLE OF CONTENTS}

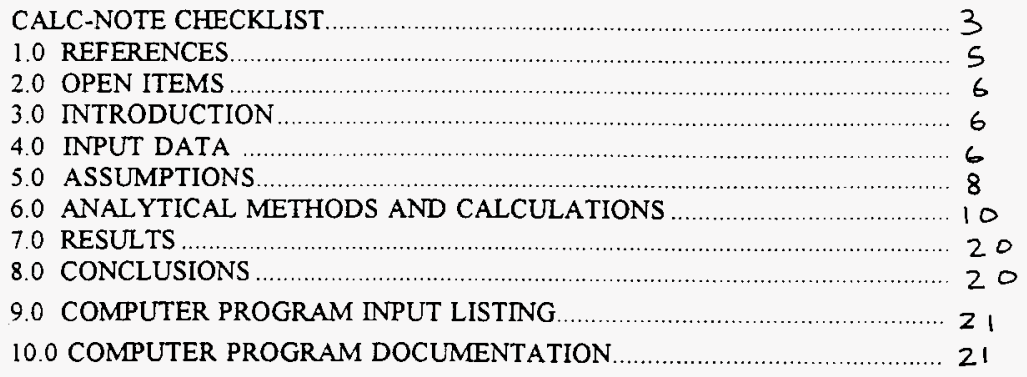




\section{CALC-NOTE CEECKLIST}

REVIEWER(S):

NAME (PRINT OR TYPE)

SIGNATURE

DATE

R. D. Graves

\section{QNogen}

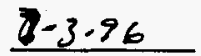

\section{CIRCLE ONE}

1. Is the Subject and/or Purpose clearly stated?

2. Are the required Input Data and their references and source provided and are they consistent with the Calc-Note purpose?

(YES NO

3. Are the Assumptions clearly identified, valid and consistent with the Calc-Note purpose?

(YES NO

4. Is the Analytical Method or Approach Used clearly identified?

(YES NO

5. Are all the pages consecutively numbered and identified by the Calc-Note number?

(YES NO

6. Is/are the version(s) of the computer program(s) used identified and QA'd adequately?

(YES NO NA

7. Are input listings for all computer programs documented in this Calc-Note, and are they V\&Vd and appropriate for the intended use?

YES NO NA

8. Are the Results and Conclusions clearly stated?

(YES NO

9. Are OUTPUT documents included (or if not part of the calculation, clearly referenced in the Results section?) grammatically, correct, clear,

YES

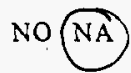
and consistent with the main calc-note text?

10. Are the results, methods, input, and assumptions compatible with the stated purpose?

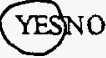

IF NO TO ANY OF THE ABOVE, LIST SHEET NUMBER(S) WITH JUSTIFICATION AND OBTAIN MANAGER'S SIGNATURE BELOW:

Manager's Signature

REVIEWER'S NOTES (use additional pages as necessary)

Review method used:

Y
Alternate calculation Attached? 


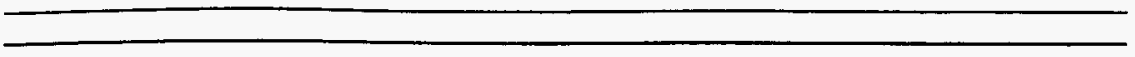




\subsection{REFERENCES}

1. Nuclear Safety Analysis Reports, DOE Order 5480.23, Change I, U. S. Department of Energy, Washington, DC, March 1994.

2. Facility and Process Description, WHC-SD-WM-SAR-067, Rev. A.

3. Information Validation Form (IVF) for filter Dimensions - Open Item

4. Interim Chapter 3.0, Hazard and Accident Analysis, WHC-SD-WM-SAR-065, Rev. 0, 1995.

5. Dry Waste compactor Hazard Identification and Evaluation, SD-WM-SAR-009, Rev. 0

6. Cowley, W. L., Development of Radiological Concentration and Unit Liter Doses for Tank Waste Remediation System Final Safety Analysis Report Radiological Consequence Calculations, WHC-SD-WM-SARR-037, Rev. 0, 1996.

7. Gupta, M. K./ Leach, D. S., The dose rate at $30 \mathrm{~cm}$ from HEPA filters in the TWRS would be less than $150 \mathrm{mr} / \mathrm{hr}$. Information Validation Form (IVF) \# MKG-Chapter 3-01.

8. Savino, A. V., MICROSHIELD Dose Rate Calculations for HEPA Filters and Pre-Filters, WHC-SD-WM-CN-033, Rev. 0, 1996, Westinghouse Hanford Company, Richland, Washington.

9. Deleted.

10. Van Keuren, J. C. and Savino, A. V., Tank Waste Compositions and Atmospheric Dispersion Coefficients for Use in Safety Analysis Consequence Assessments, WHCSD-WM-SARR-016, Rev. 2, 1996, Westinghouse Hanford Company, Richland, Washington.

11. Airborne Release Fractions/Rates and Respirable Fractions for Nonreactor Nuclear Facilities. Volume 1 - Analysis of Experimental Data, DOE-HDBK-3010-94, December 1994. 
1. The IVF for Filter Dimensions needs to be confirmed.

\subsection{INTRODUCTION}

The consequence calculated in this calc-note is for the HEPA (High Efficiency Particulate Air) fire (and subsequent unfiltered release) accident. This accident analysis was performed to support the Final Safety Analysis Repor (FSAR) for Tank Waste Remediation System (TWRS) that conforms to DOE Order 5480.23 (Ref. 1). Passive or active ventilation is maintained across each waste tank, double contained receiver tanks (DCRTs), 204-AR, 244-AR, compactor building, and catch tanks. A failure of heater can cause a fire in the ventilation system or a fire around the ventilation system can degrade the filters. The integrity of the filters (HEPA and prefilters) could be compromised by a filter fire resulting in a release of the inventory on the filters and unfiltered release of tank contents. The detailed description of the waste tanks, 204-AR, 244-AR, compactor building, and catch tanks is in chapter 2.0 of the TWRS FSAR (Ref. 2).

A frequency of Anticipated (> 1.0 E-02/yr) and Unlikely ( $1.0 \mathrm{E}-04 / \mathrm{yr}$ to $1.0 \mathrm{E}-02 / \mathrm{yr}$ ) was qualitatively assigned to the active ventilation systems (with heaters) and passive ventilation system (without heaters), respectively. These frequencies are based on the operational history of the Hanford Tank Farms.

\subsection{INPUT DATA}

The following input data were used fro the consequences analysis:

- The filter configuration is from Chapter 2 of the TWRS FSAR (Ref. 2) and the dimension of the filter from IVF (Information Validation Form) (Ref. 3).

- SSTs (Single Shell Tank) active ventilation flow rate $=3.30 \mathrm{cubic} \mathrm{m} / \mathrm{s}(7,000 \mathrm{cfm})$ (Ref. 2).

- SSTs passive ventilation flow rate $=6.8 \mathrm{E}-4 \mathrm{cubic} \mathrm{m} / \mathrm{s}$ (Ref. 4)

- DSTs (Double Shell Tank) active ventilation flow rate $=5.50 \mathrm{E}-\mathrm{I}$ cubic m/s $(1,170 \mathrm{cfm})$ (Ref. 2).

- AWF, DSTs (Double Shell Tank) active ventilation flow rate $=1.89$ cubic $\mathrm{m} / \mathrm{s}(4,000$ cfm) (Ref. 2).

- DCRTs (Double Contained Receiver Tank) active ventilation flow rate $=1.98 \mathrm{cubic} \mathrm{m} / \mathrm{s}$ $(4,200 \mathrm{cfm})$ (Ref. 2).

- $\quad$ 204-AR active ventilation flow rate $=9.44 \mathrm{E}-1$ cubic m/s $(2,000 \mathrm{cfm})$ (Ref. 2).

- 244-AR active ventilation flow rate $=7.08 \mathrm{cubic} \mathrm{m} / \mathrm{s}(15,000 \mathrm{cfm})($ Ref. 2$)$.

- Compactor building active ventilation flow rate $=9.44 \mathrm{E}-1$ cubic $\mathrm{m} / \mathrm{s}(2,000 \mathrm{cfm})$ (Ref. 5).

- Catch tanks (241-A-417 and 241-AX-152) have inlet HEPA filters only (Ref. 2). 
- The unit liter dose (ULD) for different waste streams is from Reference 6 . The table containing ULD is attached in Appendix B. 
WHC-SD-WM-CN-062 REV 0

$$
\begin{array}{r}
\text { S-CLC- } 6-00125 \\
\text { sweet? }
\end{array}
$$

5.0 ASSUMPT IONS

The following assumptions were used in this analysis:

1. Dose rate at contact from pre-filters and HEPA filters is $\leq 200 \mathrm{mR} / \mathrm{kr}$. According to Information Validation form (IVF), HEPA tilter are changed when the contact dose rate is $160 \mathrm{mR} / \mathrm{ke}$ (Ref. 7). The location for calculating contact dose rate in prefilten and HEPA filters is defined in Reference 8 .

2. All the filters are compromised and release then content during ${ }^{\circ}$ tire in or around the ventilation system.

3. The ventilation system remains in operation during and following the tire.

4. The CAM-intulock ividetect and slut - off the ventilation system within 10 minuter for DITs, 244-AR and SS Is.

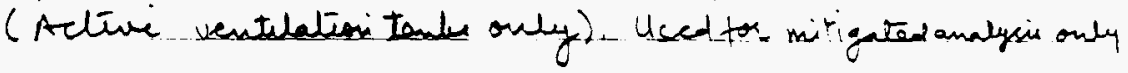

5. An additional amount equal to the loading on kse-filler or HEPA filter is used in order tu account for accumulation in the ventilation duct wore.

(of)

6. The occupancy factor f tor the maximum onsite individual is assumed to be 1.0 and 0.286 tor a 12 -hour and a lear release, respectively. The of for a maximum

\& BeTTI AVALABLE COPY 
WHC-SD-WM-CN-062 REV 0

S- che- $4-00125$ sheet 9

offsite individual is 1.0 .

7. The respirable traction (RF) for unfilled release is 1.0 tor all cases.

Pcustition Factor

8 The $(P F)$ for sst. act, sst pas 1, sst pas 2, dent, 204-Ar, gid 244-AR is $1.0 E-10$ and Pftordst, liq and sta $w+d$ is $1.0 E-8$.

9. The airborne trelears fraction (A RF) is $1 . O E-4$ for a filter the from Reference 11

10. There is no liquid in Compactor Building a Catch tenter

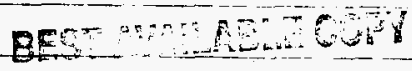

9 
WHC-SD-WM-CN-062 REV 0

S-CLC-G-00125
Sheet 10

6.0 ANALYTICAL METHOIS AND CALCULATIONS

Passive or active ventilation is maintained across each waste tank, double contained recenter tanks ( $D \subset R T_{5}$ ), 2 dAR, 244-AR, compactor building and catch tank e. A failure of heater can cause a fie in the ventilation system or a fire around the ventilation system can decade lir filters. The integrity of the tilltire (H EPA and prefiltere) could be compromised by a filter fire resulting in a release of the inventory on the filling and unfiltered release of tank contents.

The hazard aneles is performed forth Tues facilities identified two potential scenario x:

A. An unfiltered release due to failure of $H E P A$ filter

B. A fitter fir in or around the ventilation system and subsequent unfiltered, release of lan de contents (head space gases).

Scenario A.

The details of methodology weed to calculate the onsite and offsite consequences un unlined relax are in Reference 4

and off sita

The onsite thadiological dose consequences are calculated by the following equation:

10 BEST AVAILABLE COPY 
WHC-SD-WM-CN-062 REV 0

$$
\begin{array}{r}
\text { S- LC- G- } 00125 \\
\text { Sheet } 11
\end{array}
$$

Dose (SV) $=O F \times X / Q \times R \times U L D \times Q^{\prime} \times t$

where,

OF = Occupancy factor, for 12 hour release it is assumed to be 1.0. It is assumed to be 0.286 tor an onsite release that late a year. The of for a maximum offsite individual is 1.0

$X / Q=$ Atmospheric dispersion coefficients are from reference 10.

$R=$ Breathing Rate, $2.7 \times 10^{-4} \mathrm{~m}^{3} / \mathrm{s}$ for a. 24 -hour release offsite and 1-year release onsite and offsite and $3.3 \times 10^{-4} \mathrm{~m}^{3} / \mathrm{s}$ for a 12 -hour release onsite

ULD = Unit-litu-dose value for diffluent wart type on in Appendix B.

$t=$ period of release (in seconds)

$Q^{\prime}=$ Release rate $(l / s)$

The $Q^{\prime}$ is defined as:

$$
Q^{\prime}=R F \times(1-e) \times V \times P F
$$

when,

$R F=$ Respirable traction. It is assumed to be 1.0 to all cases.

BEST AVAILABLE COPY 
WHC-SD-WM-CN-062 REV 0

$S-\angle L C-G-0012$

$e=H E P A$ titter efficiency, it is assumed to be 0.0 .

$V=v$ volume flow nate of the effluent, $\mathrm{m}^{3} / \mathrm{s}$

$P F=$ Partition factor. A partition factor of $10^{-10}$ is used for solids and unagitated liquids and a PF of $10^{-8}$ is used for agitated liquids.

The dispersion coefficient for 12-hour and 24-hour release are calculated from the methodolson guin in Reference 10 .

X10, onsite (12-hous)

From Table 4 of efferencelo, $x / Q$ for 2 -hour culex is $3.41 E-2 \mathrm{~s} / \mathrm{m}^{3}$; X la for annual release $(8760$ hour) from $T$ able 9 of reference 10 is $4.03 \times 10^{-4}$

$$
\begin{aligned}
\frac{\log \left(3.41 \times 10^{-2}\right)-\log (\times / 0,12 \mathrm{mow})}{\log \left(3.41 \times 10^{-2}\right)-\log \left(4.03 \times 10^{-4}\right)} & =\frac{\log (2 \mathrm{~m})-\log (12 \mathrm{~mm})}{\log (2 \mathrm{~m})-\log (8760 \mathrm{~m})} \\
x / 2 \text { ta } 12 \text { hansaclease } & =1.32 E-2 \mathrm{~s} / \mathrm{m}^{3}
\end{aligned}
$$

$x / 2$, off site (24-hour)

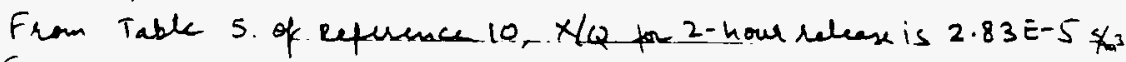
From table 9 of references 10 , $\times 1 Q$ thennual (8760 W) release is $1.24 E-7$ 12 BEST AVAILABLE COPY 
WHC-SD-WM-CN-062 REV 0

$$
\begin{gathered}
\text { S.CL<-4-00125 } \\
\text { stent } 13
\end{gathered}
$$

$$
\frac{\log (2.83 E-5)-\log (\times / 0,24 \mathrm{knen})}{\log (2.83 E-5)-\log (1.24 E-7)}=\frac{\log (2 \mathrm{ma})-\log (24 \mathrm{hom})}{\log (2 \mathrm{ku})-\log (8760 \mathrm{kr})}
$$

The tables are attached in Appendix B.

The onsite and offsite inhalation doses are calculated for different ventilation system. The methodoly of calculating different onsite and offsite doses is:

12- hour Onsite doses

$$
\begin{aligned}
& \text { Common parameter in equation } 1=O F \times \times / Q \times R \times t \\
& =\quad \cdots=1.0 \times 1.32 E-25 / m_{0} \times 3.3 E-4 \mathrm{~m}^{3} / 5^{n} \\
& \text {.......... hours } \times 3600 \% \\
& =1.88 E-1.5 \text {. }
\end{aligned}
$$

Thus is defined as (hid onsite $(1.88 \mathrm{E}-1)$ in the excel spread sect in Appendix $A$.

The doses are then calculated by multiplying the flow

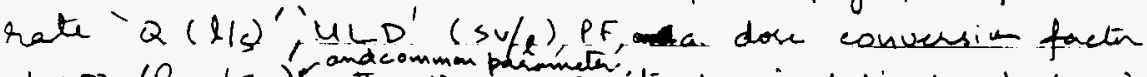
of 100 (Rem/sv). The 12 -hour onsite dose is defined a don (rem) in the excel spreadsheet in Appendix $A$, The flow rate $Q$ ' and ULD se the input data and PF is defined in assumptions. the calculations if SST, of $x$ :

The How hate is $3.3 \mathrm{~m}^{3} / \mathrm{s}$ (input data) or $3.3 \times 10^{3} \mathrm{l} / \mathrm{s}$ the PF is $1.0 E-10$ (assumptions)

$U L D$ is $2 \cdot 2 E+5$ Sue

13 BEST AVAILABLE COPY 
WHC-SD-WM-CN-062 REV 0

$$
\begin{aligned}
\therefore \text { don }(\text { rem }) & =3.3 E+3 l / \mathrm{s} \times 1.0 E-10 \times 2.2 E+55 \% \text { l } \times 100 \mathrm{hem} / \mathrm{siv} \times 1.88 \mathrm{e}^{5-1} \mathrm{~s} . \\
& =1.37 \mathrm{rem}
\end{aligned}
$$

This is the value for SSt ct under don (rem) in the excel spreadsheet in Appendix $A$.

The 12-hour onsite doses are calculated for sstpasi, sst par 3 dirt, dstli,dst astr, 204-ar, 244-or in a similar way. The doses tor sst pas 1 and sst pas 2 are same because the flow rate is same and only the dimension of HE PA filter ane different.

Annual Onsite doses

$$
\begin{aligned}
& \text { Common parameter in equation } 1=O E \times x / Q \times R \times t \\
& =0.286 \times 4.03 E-45 / 2 \times 2.7 E-4 \frac{3}{3} \\
& -365 \text { dayex } 24 \text { by } * 3600 \text { s/hou } \\
& =9.81 E-1 \leqslant
\end{aligned}
$$

This is defined ar Chi Onsite $(9.81 E-1)$, in the excel spread sheet in Appendix A. andcommontaranch The doses are then calculated by multiplying the How nate. 'Q( BVS) 'ULD'. (SUPt), PE and a dos conversion factor of $100\left(\mathrm{~km} / \mathrm{S}_{0}\right)$." The annul onsite dose is defined as divan (rem) in the excel spread sleet in Appendix A

The calculation for sst, act is:

$$
\begin{aligned}
\text { donann } & =3.3 E+3 \mathrm{l} / \mathrm{s} \times 1.0 E-10 \times 2.2 E+5 \mathrm{~s} / \mathrm{t} \times 100 \mathrm{Rem} / \mathrm{su} \times 9.81 E-1 \mathrm{~s} \\
& =7.12 \mathrm{rem}
\end{aligned}
$$

Thus is the value for sst, act undue domain (no ming the excel spread shat in Appendix A.

The a rumal onsite doses th sst pas!, sst pase dent, dst liq, dst auth, 204.x1, and 244 -ar are calculated in a similar way.

14. BEST AVAILABLE COPY 
WHC-SD-WM-CN-052 REV 0

$S-C L C-G-00125$

sheet 15

24-hour Offsite Dose

Compton para meters in equation 1. of $\times \times / Q \times R, t$

$$
\begin{aligned}
& =1.0 \times 5.66 E-6 \mathrm{~s} / \mathrm{m}^{3} \times 2.7 E-4 \mathrm{~m}+\mathrm{s} \text {. } \\
& =24 \text { how } \times 3600 \mathrm{~s} / \text { how } \\
& =132 E-4 \mathrm{~s}
\end{aligned}
$$

Then is defined as Chi offsite $(1.32 E-4)$ in The excel spreadsheet in Appendix $A$.

The doses are then calculated mprmeltipleyin How rate, ULD, PF,

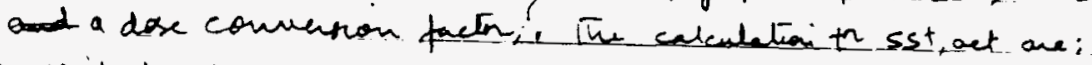

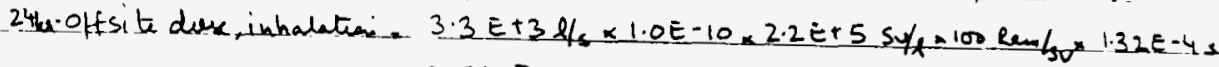

$$
-\quad=9.58 E-4 \text { rem }
$$

The offsite doses include lo contribution of the inqution doses alto. The ingestion doses are calculated by the follows equation from Ref. 10

$$
\begin{aligned}
& \text { Dose, inqustion }=Q^{\prime}(1 /)^{2} \times X / Q\left(3 / \mathrm{m}^{3}\right)=U L D \frac{\left(s_{v}-m^{3}\right) \times t}{s-1} t(s)=(2) \\
& Q=R F \times(1-e) \times V \cdot(l / 5) \times P F
\end{aligned}
$$

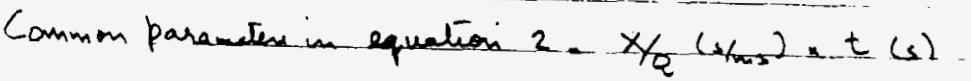

$$
\begin{aligned}
& =5.66 E-6(5 / \mathrm{m}) \times 24 \text { ham } \times 3600 \mathrm{~s} / \mathrm{ham} \\
& -4.89 E-1 \mathrm{~s}^{2} / \mathrm{m}^{3}
\end{aligned}
$$

Then is defined as second chi 9 attsite $(4.89 E-1)$ in the excel spreadshed in Appendix $A$.

The doses are then calculated multiplying lt e flow sate, PF, U LD and a dose conversion factors the calculation e to sst act are:

on d common parament.

is BEST AVAILABLE COPY 
WHC-SD-WM-CN-062 REV 0

$5-\ll c-c-00125$ Sheatio

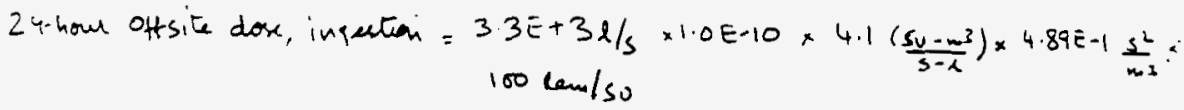

$$
\begin{aligned}
& =6.61 E-5 \text { rem }
\end{aligned}
$$

The 24. hour off site dose is then sum of inhalation and ingestion doses defined as doffitrem) in excel spread sheet in Appendix

$$
d \text { off (ram) }=9.58 E-4+6.61 E-5=1.02 E-3 \mathrm{rmm}
$$

The is the value for sst. al under dott(rem) in the excel spread sheet in Appendix $A$.

The 24 -hour offsite doss th sst past, sst pas z, dent, dst liq, dstawt, 204-as, and 244-ar are calculated in a similar way.

Annual Offsite Doses

Common parameter in ration $1=Q F \times \times / Q \times R \times t$

$$
\begin{aligned}
& =10 \times 1.24 E-7 \mathrm{~s} / \mathrm{m}_{3} \times 2.7 E-4 \mathrm{~m}^{3} / \mathrm{s}< \\
& 365 \text { dey } 24 \text { ham } \cdot 3600 y \text { ham }
\end{aligned}
$$

this is defined as chit offset $\operatorname{tnn}(1.068-3)$ in the excel if read shat in appendix $A$.

The doses are the calculated on multiplying the flow rate, $U L D, P F$, a dose conversion factor? The calcubtion for sst, act one:

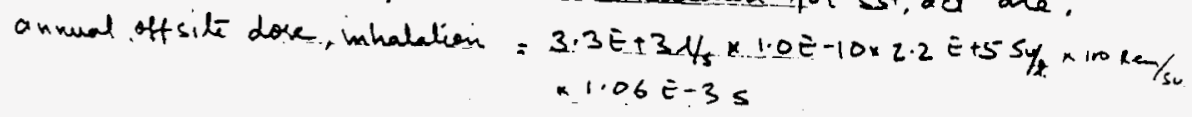

$$
\begin{aligned}
& .1 .06 \mathrm{E}-3 \mathrm{~s} \\
= & 7.66 \mathrm{E}-3 \mathrm{~mm} .
\end{aligned}
$$

it BEST AVAILABLE COPY 


\section{ᄉd0J $379 \forall 7 \mid \forall A \forall \perp S \exists g$}

- hrom

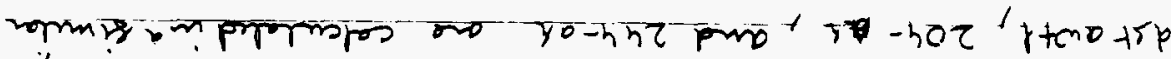

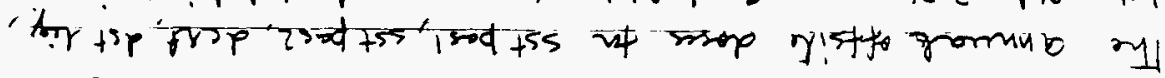

7 rperatit in porms

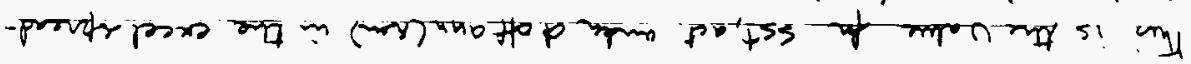

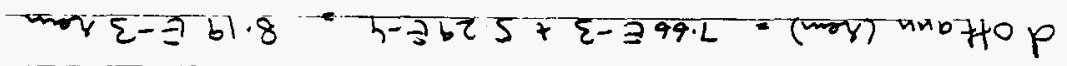

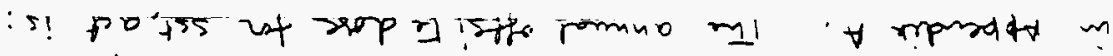

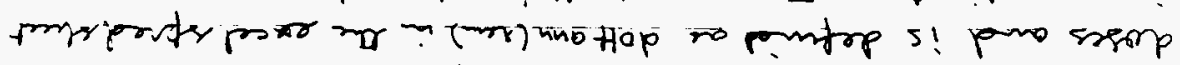

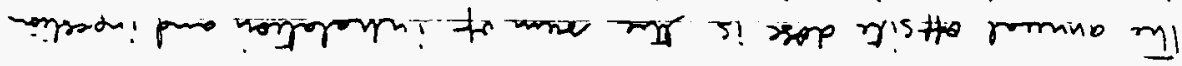
zisy h-abr.5 =

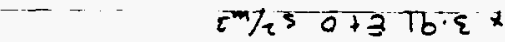

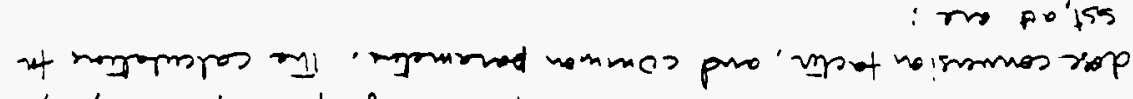

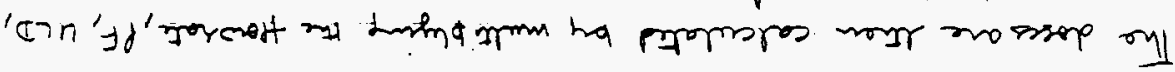

$\forall$ xpondty un prosponsty

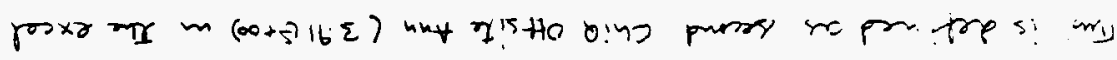

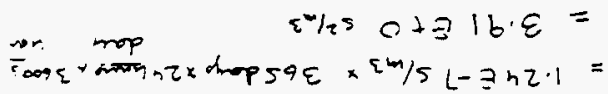

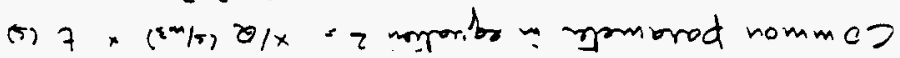

Li froms

ST100-h- $\rightarrow 70-5$ 
WHC-SD-WM-CN-062 REV 0

$$
\begin{array}{r}
\text { S-CLC-G-00125 } \\
\text { Shear } 18
\end{array}
$$

Toxicological Doses

The methodology to calculation taxi oological doses is described in Reference 10. The following equation is wed to calculak

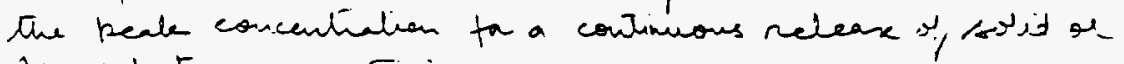
Dip ind tox. - matisia.

Dose $=$ Sum of Fractions $\& Q^{\prime}$

Sum of Fraction is defined in Table 3-8 (attached in Appendix) different ware types and ac a function of accident frequency.

Onsite

$$
Q^{\prime}=V_{P S} \rho E
$$

For sst. act. The summon paction from Table $3-8$ is $4.0 E+4 \mathrm{~s} / \mathrm{e}$. (defined as ' SOF (te)' in the excel spread sheet is appendix A)

$$
\begin{aligned}
\theta^{\prime} & =3.3 E+3 / / 5 \times 1.0 E-10=3.3 E-7 \mathrm{l} / \mathrm{s} \\
\text { Dose, onsite }=3.3 E-7 \mu_{5} \times 4.0 E+4 & =1.32 E-2
\end{aligned}
$$

Then is the value th sst, act under. Dore onsite $(1.32 \div-02)$ in the excel spread sheet in Appendix. A

The onsite toxicological dore tu sst pal, sst pas 2, dost, dst liq, dst aw h, 204 -ar, and $24 h-a r$ are calculated in a similar way

18 BEST AVAiLABLE COPY 
WHC-SD-WM-CN-062 REV 0

$S-C L C-9-00125$

sect 19

2\#sice

Fo cst, ad, the offsite sum of traction from Table $3-8$ is $9.4 E+O 1$ (define) as SOF (si) in the excel spreadsheet in Appendix A.

$$
\text { Dose, offsite }=3.3 E-7 \mathrm{l} / \mathrm{s} \times 9.4 E+01 \mathrm{~s} / 2=3.1 E-5
$$

This is the value the sst, act (3.1E-05) under Dose offsite in the excel spreadsheet in Appendix $A$.

The offsite toxicological dose for sst pas , sst pas z, dent, dst life, dst aw fl, $204-a r$ and 244 -an one calculated in a similar way.

Scenario B

The methodology and doses pom the pile fire are in Appendix B.

The unfiltered release that occur oft er the pith the are calculated in Scenario A

The combined radiologien and toxicological dose consequence to Scenario B are in Table 1. Thess consequences are the sum of consequences calculated in Appendix B and Schematic A The puff release toxicological consequence are used from Appendix $B$. It is assumed that no liquid ore present in compactor building and catch tanks preserve there is wo contribution

${ }^{19}$ BEST AVAILABLE COPY 
WHC-SD-WM-CN-052 REV 0

$$
\begin{aligned}
& \text { S-CLC-G-00125 } \\
& \text { Sheet } 20
\end{aligned}
$$

due To unfiltered release

TO RESULTS

The unmitigated radiological doses from unfillined releases (U.R) for Single shell I andes (SIs) with a clive ventilation. Double shell Tanks (DSTS) and 244-AR, shown in Table 1, are above onsite risk evaluation guideline of 0.5 rem. Therefore, a safety significant $\angle A M$-interlock to detect potential unfiltered relearn and to shut off ventilation within 10 minutes is require tor the ventilation system on SST (with active ventilation only), $D S T$ is and $244-A R$.

The mitigated onsite radiological consequence for s sis (with active ventilitini). DST s, and 244. AR are shown in Table 2. The calculation were perfumed acstdri to the methodology described in scenario and shown. in $\operatorname{don}(\mathrm{rem})$ in the excel spread sheet in Appendix. A (sheet 2) The mitigated onsite radiological doses tor ISIs (withative ventilation), ISIs, and 244-AR are orders of magnitude below the evaluation guideline of 0 . Siam

8.0 CON CLUSTONS

The unmitigated onsite and off site radiological and Toxicological consequences are well within the evaluation guidelines (0.5 hem and 1.0 -onsite and 0.1 rem ad 1.0 -offsite)

20 BEST AVAILABLE COPY 


\section{$\Lambda d 00 \exists 79 \forall 7 \mid \forall \wedge \forall \perp S \exists g$}

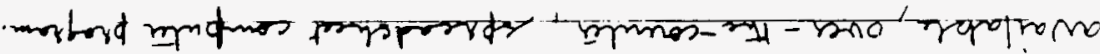

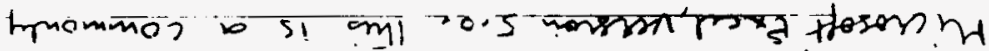

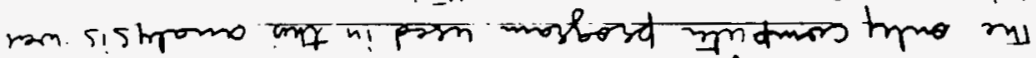

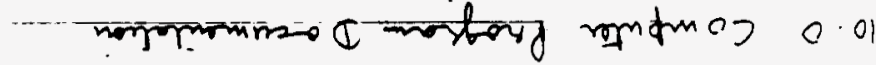

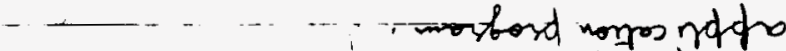

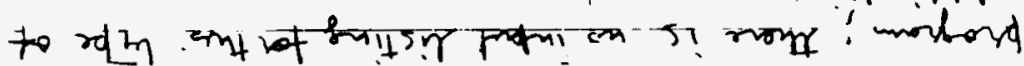

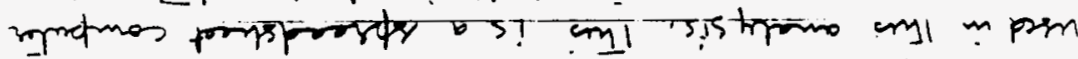
ram (O.snoins smopin!

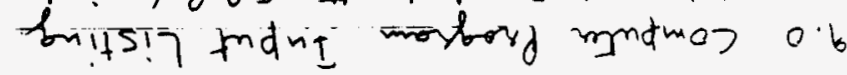

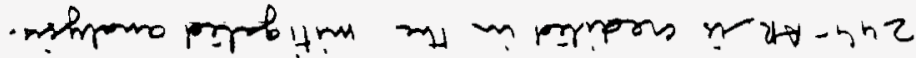

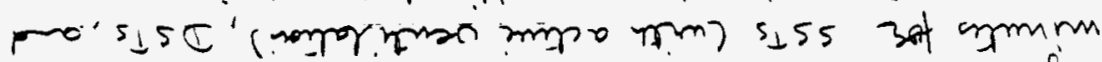

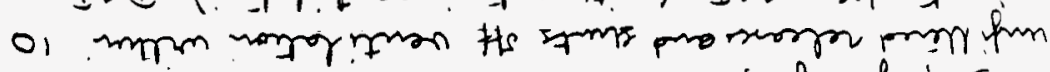

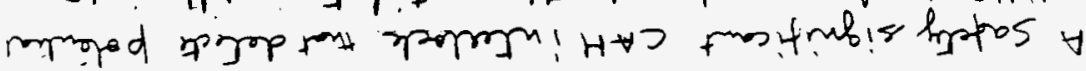
. mmpporrs

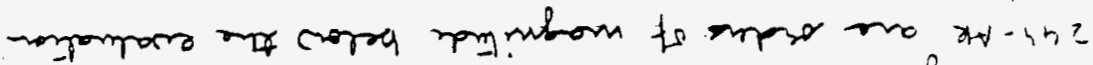

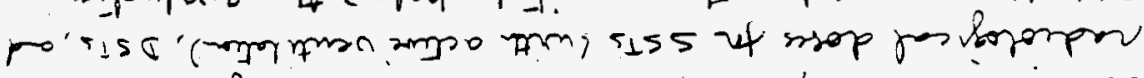

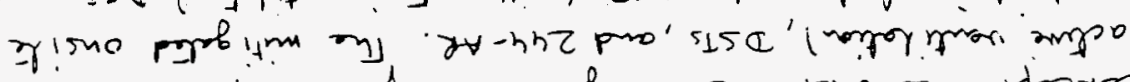

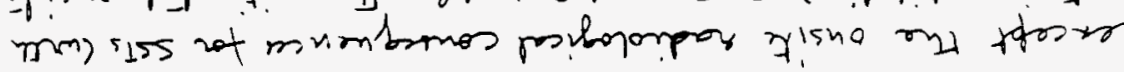


WHC-SD-WM-CN-062 REV 0

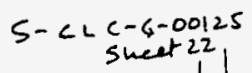

(3)

$\Rightarrow$

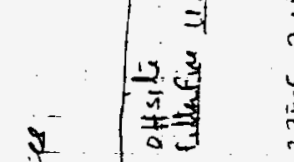

8

क

-

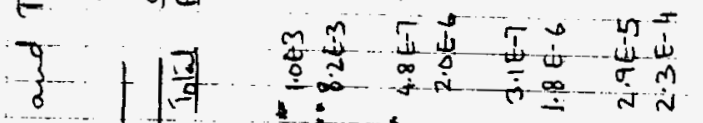

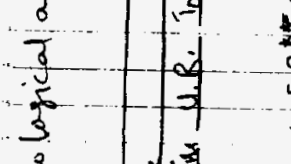

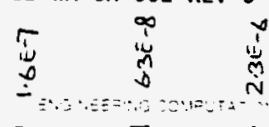

类

ก 4 ก

तो

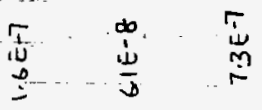

$\frac{1}{4}$

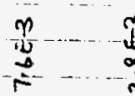

$\stackrel{4}{n}$

$\underset{2}{2}+2$

$\underset{5}{5}$

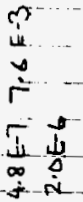

m.

m?

\section{N N}

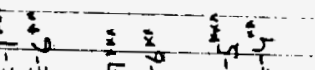

$\frac{1}{2}$

$=1$

ज.

$\frac{\sqrt{1}}{4} \dot{w}$

ले

is.

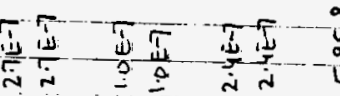

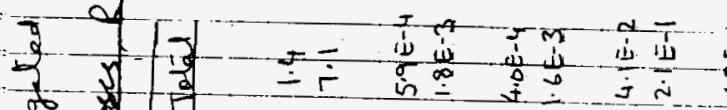

2 \&

से से

$5-3$

$\Rightarrow$

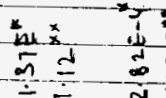

in:

$\sin$

I $=\frac{1}{4}$

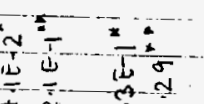

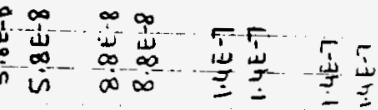

$-m=m$ ?

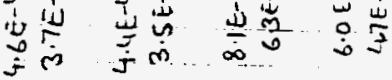
击 $\dot{r} \dot{0}$ is

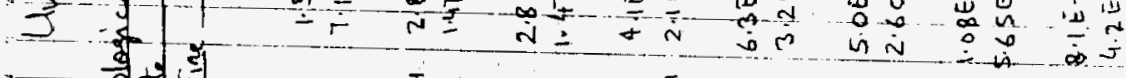

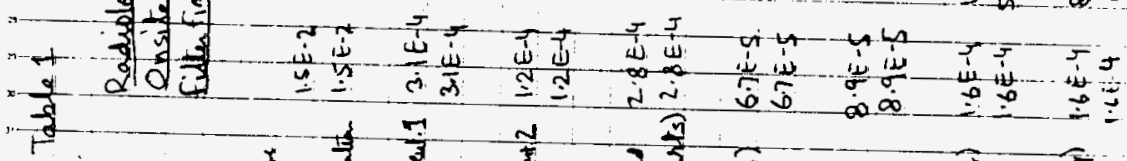

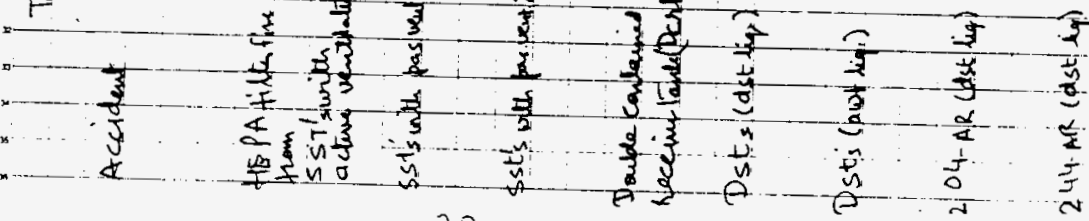

22 


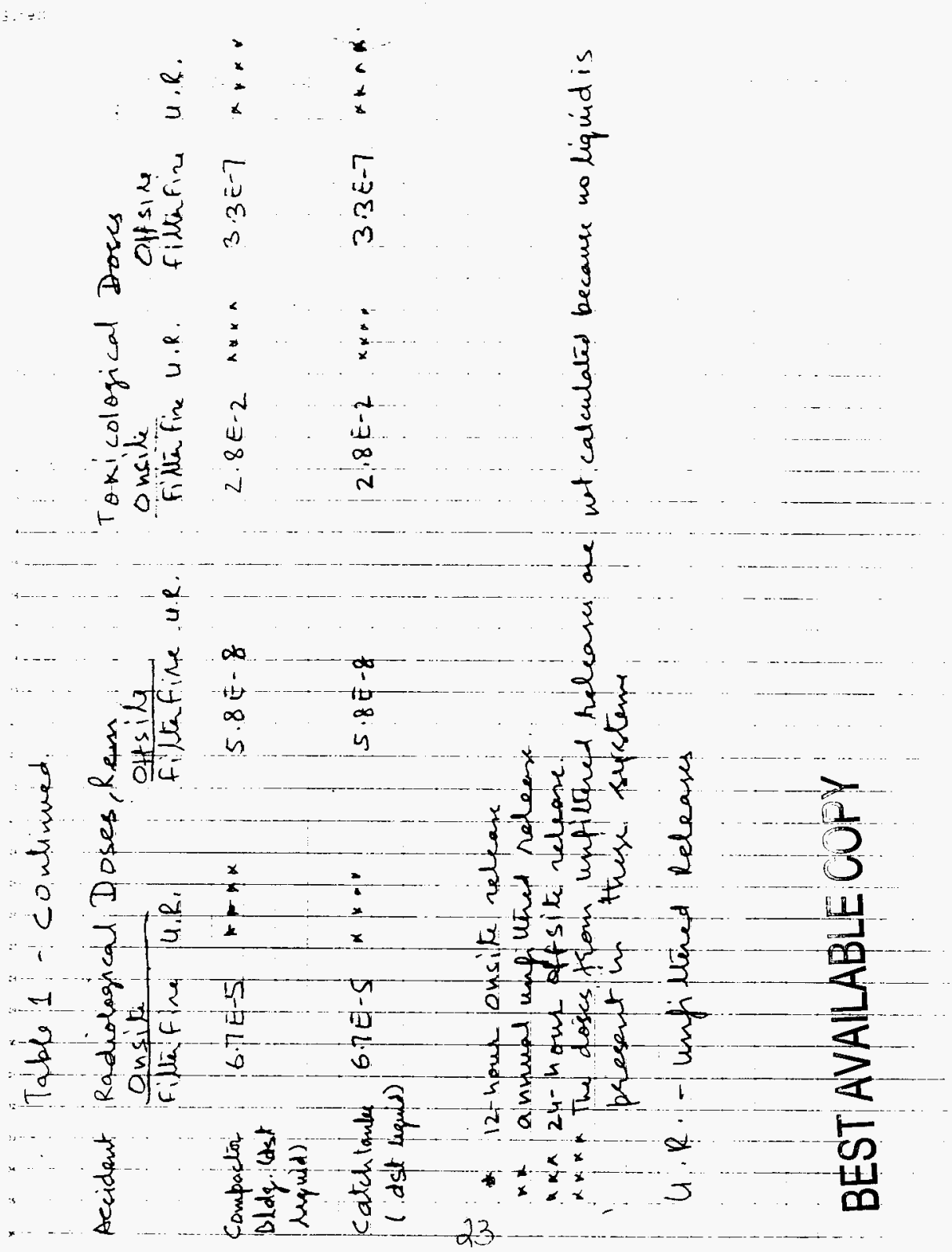




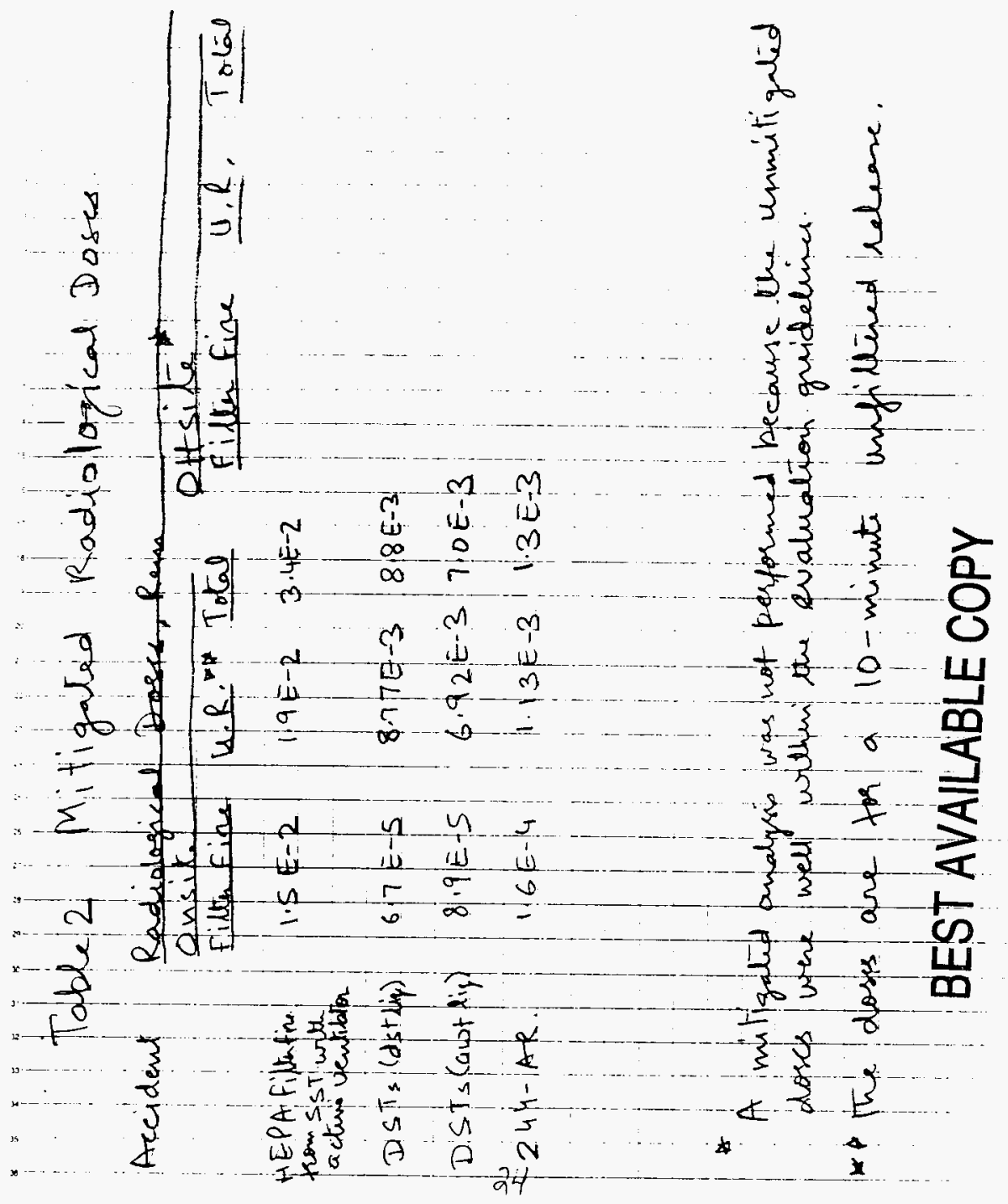


WHC-SD-WM-CN-062 REV 0

S-CLC-4-0012!

sheet 25

Appendix A Dose Consequences of Unfiltered Releases.

25 BEST AVAILABLE COPY 


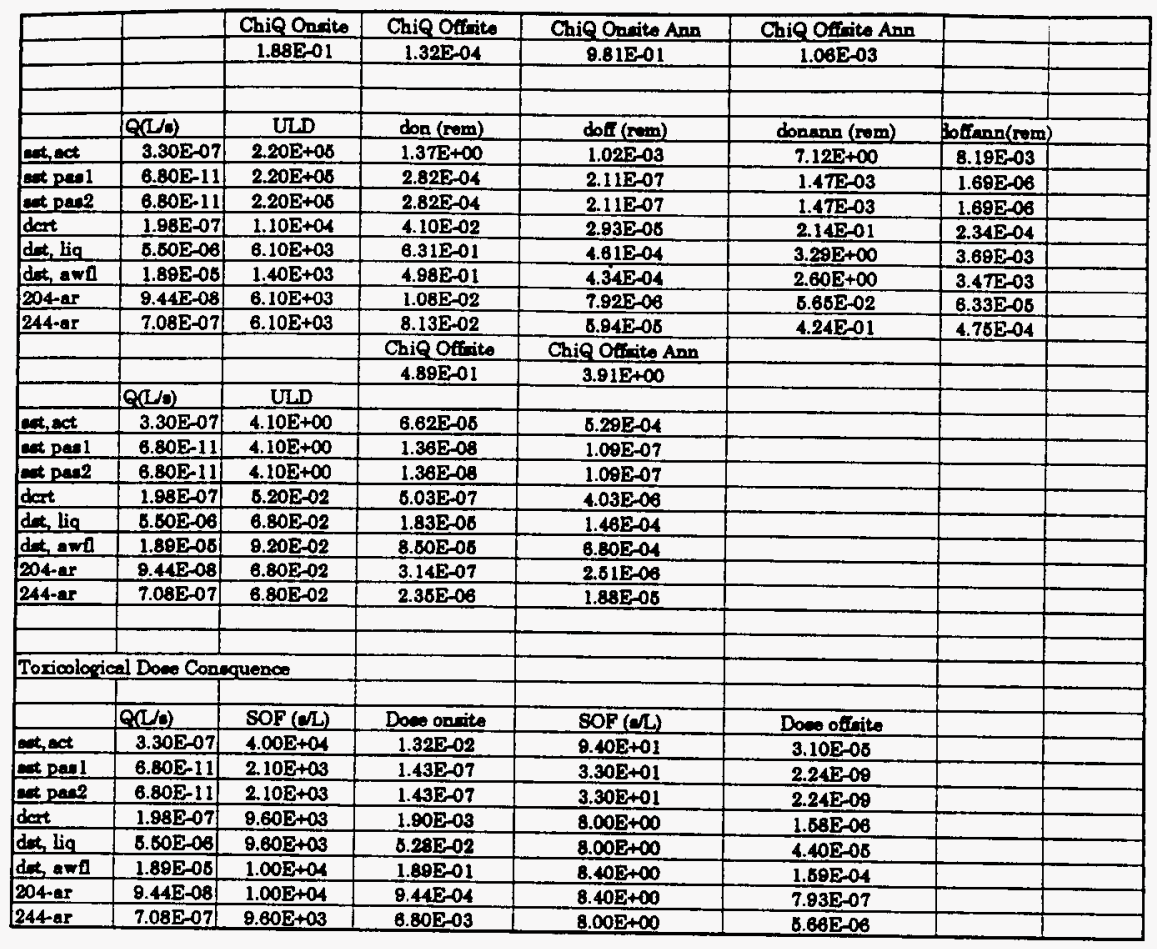

Page 1 


\begin{tabular}{|c|c|c|c|c|c|c|c|}
\hline & & ChiQ Onaite & Chil Orfite & ChiQ Onrite Ann & Chie Offite Ann & & \\
\hline & & 2.61E-03 & $1.32 \mathrm{E}-04$ & $0.81 \mathrm{E}-01$ & $1.06 \mathrm{E}-03$ & & \\
\hline & & & omin 4.8 & & & & \\
\hline & $Q(L / s)$ & ULD & $\operatorname{don}(\mathrm{rem})$ & doff (rem) & donann (rom) & Bffann(rem) & \\
\hline etsect & $3.30 \mathrm{E}-07$ & $2.20 \mathrm{E}+0.5$ & $1.90 \mathrm{E}-02$ & $1.025-03$ & $7.122+\infty$ & $8.19 \mathrm{E}-03$ & \\
\hline t peel & 6.80E-11 & $2.20 \mathrm{E}+0 \mathrm{5}$ & $3.01 E-06$ & $2.11 \mathrm{E}-07$ & $1.472-03$ & $1.69 \mathrm{E}-06$ & \\
\hline $4+$ pace & $6.80 \mathrm{E}-11$ & 2.20E+05 & $3.81 \mathrm{E}-06$ & $2.115-07$ & $1.47 E-03$ & $1.69 \mathrm{E}-08$ & \\
\hline dent & $1.98 \mathrm{E}-07$ & $1.10 \mathrm{E}+04$ & $6.69 \mathrm{E}-04$ & $2.93 \mathrm{E}-08$ & 2.14E-01 & $2.34 \mathrm{E}-04$ & \\
\hline ds liq & 5.80E-06 & $6.10 \mathrm{E}+03$ & $8.77 \mathrm{E}-03$ & $4.61 \mathrm{E}-04$ & $3.29 \mathrm{E}+\infty$ & $3.60 \mathrm{E}-03$ & \\
\hline dex arf & $1.89 \mathrm{E}-05$ & $1.40 E+03$ & $6.92 \mathrm{E}-03$ & $4.34 E-04$ & $2.60 \mathrm{E}+00$ & $3.47 \mathrm{E}-03$ & \\
\hline 204 -ar & $9.44 \mathrm{E}-08$ & $6.10 E+03$ & $1.61 \mathrm{E}-04$ & $7.92 \mathrm{E}-06$ & $5.66 \mathrm{E}-02$ & $6.335-05$ & \\
\hline 244-ar & $7.08 \mathrm{E}-07$ & $6.10 \mathrm{E}+03$ & $1.13 \mathrm{E}-03$ & $6.94 \mathrm{E}-00$ & $4.24 \mathrm{E}-01$ & 4.75E-04 & \\
\hline & & & Chis Ofrite & ChiQ Ofiate Ann & & & \\
\hline & & & $4.89 \mathrm{E}-01$ & $3.91 \mathrm{E}+\infty$ & & & \\
\hline & $Q\left(\omega_{0}\right)$ & ULD & & & & & \\
\hline$e x$, act & $3.30 \mathrm{E}-07$ & $4.10 \mathrm{E}+00$ & $6.625-05$ & $5.29 \mathrm{E}-04$ & & & \\
\hline atpan 1 & 6.80E-11 & $4.10 \mathrm{E}+00$ & $1.36 \mathrm{E}-08$ & $1.00 E-07$ & & & \\
\hline -tpen & 6.80E-11 & $4.10 \mathrm{E}+00$ & 1.36E-08 & $1.00 \mathrm{E}-07$ & & & \\
\hline det & 1.89E-07 & $6.20 \mathrm{E}-02$ & 6.03E-07 & $4.03 \mathrm{E}-06$ & & & \\
\hline dat, liq & $5.50 \mathrm{E}-08$ & $6.80 \mathrm{E}-02$ & $1.83 \mathrm{E}-08$ & 1.46504 & & & \\
\hline dt awd & $1.89 \mathrm{E}-06$ & $9.20 \mathrm{E}-02$ & 8.60E-06 & $6.80 \mathrm{E}-04$ & & & \\
\hline 204-ar & $9.44 \mathrm{E}-08$ & $6.80 \mathrm{E}-02$ & $3.14 \mathrm{E}-07$ & $2.81 \mathrm{E}-06$ & & & \\
\hline 244-ar & $7.085-07$ & 6.80E-02 & $2.36 \mathrm{E}-0 \mathrm{6}$ & $1.88 \mathrm{E}-0 \mathrm{~B}$ & & & \\
\hline & & & & & & & \\
\hline & & & & & & & \\
\hline \multicolumn{8}{|c|}{ Toxicolorical Does Conequence } \\
\hline & & & & & & & \\
\hline & $Q(\mathrm{LO})$ & $\operatorname{SOP}(\mu)$ & Doee onrite & SOF $(1)$ & Dopes offrite & & \\
\hline at,act & $3.30 \mathrm{E}-07$ & $4.00 E+04$ & $1.325-02$ & $9.40 \mathrm{E}+01$ & $3.105-05$ & & \\
\hline expel & $6.80 \mathrm{E}-11$ & 2. $10 \mathrm{~B}+03$ & $1.432-07$ & $3.305+01$ & $2.242-00$ & & \\
\hline etpeng & $6.80 \mathrm{E}-11$ & $2.10 \mathrm{E}+03$ & $1.435-07$ & $3.30 \mathrm{~J}+01$ & $2.2415-00$ & & \\
\hline dent & $1.88 \mathrm{E}-07$ & $9.60 \mathrm{E}+03$ & $1.90 \mathrm{E}-03$ & $8.00 \mathrm{E}+\infty$ & $1.08 \mathrm{E}-06$ & & \\
\hline dat liq & 6.50E-06 & $8.60 \mathrm{E}+03$ & $8.285-02$ & $8.00 \mathrm{D}+\infty 0$ & 4.40E-08 & & \\
\hline da, awd & $1.89 \mathrm{E}-08$ & $1.00 \mathrm{E}+04$ & $1.89 \mathrm{E}-01$ & $8.40 \mathrm{E}+00$ & $1.59 \mathrm{E}-04$ & & \\
\hline 204-ar & $9.44 \mathrm{E}-08$ & $1.00 \mathrm{E}+04$ & $9.44 \mathrm{E}-04$ & $8.40 \mathrm{E}+00$ & $7.93 \mathrm{E}-07$ & & \\
\hline 244-ar & $7.08 \mathrm{E}-07$ & $9.60 \mathrm{E}+03$ & 6.80E-03 & $8.00 \mathrm{E}+00$ & $6.66 \mathrm{E}-06$ & & \\
\hline
\end{tabular}

Pax 2 
Table 3-8. Sum-of-Fraction of Risk Guidelines for a Unit Release of Chemicals and Gases. (3 sheers)

*The sum of fractions are multiplied by the release rate for continuous release and release amount for a puff releases. Release rates for continuous releases are in units of liters per second for liquids and solids, and $\mathrm{m} 3 / \mathrm{s}$ for gases. Puff release quantities are in units of liters for solids and liquids and $\mathrm{m}$.? tor gases.

\begin{tabular}{|c|c|c|c|c|}
\hline \multirow{2}{*}{$\begin{array}{l}\text { Tank waste type (Units of sum of } \\
\text { tractions follow tank waste type) }\end{array}$} & \multirow{2}{*}{$\begin{array}{l}\text { Maximum } \\
\text { individua! }\end{array}$} & \multicolumn{3}{|c|}{ Accident frequency, $1 / \mathrm{yr}$} \\
\hline & & $1-10-2$ & $10-2 \cdot 10-4$ & $10-4-10-6$ \\
\hline \multicolumn{5}{|c|}{ DST or SST solid or liquid continuous release } \\
\hline Single-shell liquids(s/L) & Onsite & $9.6 E+03$ & $7.5 E+02$ & $2.0 \mathrm{E}+02$ \\
\hline Single-shell liquids(s/L) & Offsite & $8.0 \mathrm{E}+00$ & $8.0 \mathrm{E}+00$ & $6.2 \mathrm{E}-01$ \\
\hline Single-shell solids(s/L) & Onsite & $4.0 \mathrm{E}+04$ & $2.1 E+03$ & $1.0 \mathrm{E}+03$ \\
\hline Single-shell solids(s/L) & Offsite & $9.4 E+01$ & $3.3 E+01$ & $1.7 \mathrm{E}+01$ \\
\hline Double-sheil liquids(s/L) & Onsite & $1.0 \mathrm{E}+04$ & $7.5 \mathrm{E}+02$ & $2.1 E+02$ \\
\hline Double-shell liquids(s/L) & Offsite & $8.4 \mathrm{E}+00$ & $8.4 E+00$ & $6.2 \mathrm{E}-01$ \\
\hline Double-shell solids (s/L) & Onsite & $1.8 \mathrm{E}+04$ & $3.3 E+03$ & $6.3 E+02$ \\
\hline Double-shell solids(s/L) & Oftsite & $1.9 \mathrm{E}+02$ & $1.5 \mathrm{E}+01$ & $2.8 E+00$ \\
\hline \multicolumn{5}{|c|}{ DST or SST liquid or solid puff release } \\
\hline Single-shell liquids $(\mathrm{L}-1)$ & Onsite & $2.8 \mathrm{E}+03$ & $2.2 \mathrm{E}+02$ & $5.7 \mathrm{E}+01$ \\
\hline Single-shell liquids (L-1) & Offsite & $3.2 \mathrm{E}-02$ & $3.2 \mathrm{E}-02$ & $2.5 \mathrm{E}-03$ \\
\hline Single-shell solids $(\mathrm{L}-\mathrm{l})$ & Onsite & $1.2 \mathrm{E}+04$ & $6.0 \mathrm{E}+03$ & $2.9 E+02$ \\
\hline Single-shell solids $(L-1)$ & Oftsite & $3.8 \mathrm{E}-01$ & $1.3 \mathrm{E}-01$ & $6.9 \overline{E-02}$ \\
\hline Double-shell liquids (L-1) & Onsite & $2.9 \mathrm{E}+03$ & $2.2 \mathrm{E}+02$ & $6.0 \mathrm{E}+01$ \\
\hline Double-shell liquids $(\mathrm{L}-1)$ & Offsite & $3.4 E-02$ & $3.4 \mathrm{E}-02$ & $2.5 \mathrm{E}-03$ \\
\hline Double-shell solids (L-1) & Onsite & $5.2 \mathrm{E}+03$ & $9.7 E+02$ & $1.8 E+02$ \\
\hline Double-shell solids (L-1) & Onsite & $7.7 \mathrm{E}-01$ & $5.9 \mathrm{E}-02$ & $1.1 \mathrm{E}-02$ \\
\hline \multicolumn{5}{|c|}{ Flammolegas wateh list empesite } \\
\hline Entrustots & Onsite & $+3 E+04$ & $+1 E+03$ & $2.6 E+\theta$ \\
\hline Comberts) & Otfitite & $+.4 E+0+$ & $7.2 E+\infty$ & $6.1 E \theta$ \\
\hline Pyffetese (I) & Onsite & $3.7 E+03$ & $3.2 E+02$ & $7.7 E+04$ \\
\hline Puft Retere $(\mathrm{t} H$ & Ofyite & $3.4-02$ & $+.7 E-02$ & $+4 E 03$ \\
\hline
\end{tabular}


Gas Release - Worst Case Composite

\begin{tabular}{l|l|c|c|c}
\hline Continuous $(\mathrm{s} / \mathrm{m} 3)$ & Onsite & $7.7 \mathrm{E}+01$ & $9.4 \mathrm{E}+00$ & $1.9 \mathrm{E}+00$ \\
\hline Continuous $(\mathrm{s} / \mathrm{m} 3)$ & Offsite & $6.6 \mathrm{E}-02$ & $6.6 \mathrm{E}-02$ & $8.1 \mathrm{E}-03$ \\
\hline Puff $(\mathrm{m}-3)$ & Onsite & $2.3 \mathrm{E}+01$ & $2.8 \mathrm{E}+00$ & $5.8 \mathrm{E}-01$ \\
\hline Puff $(\mathrm{m}-3)$ & Oftsite & $2.7 \mathrm{E}-04$ & $2.7 \mathrm{E}-04$ & $3.2 \mathrm{E}-05$ \\
\hline
\end{tabular}

Gas Release - Maximum Sample Composite

Note this data should be used only when the accident scenario does not involve a slurty gas release Otherwise use the above sum of tractions.

\begin{tabular}{|c|c|c|c|c|}
\hline Continuous (s/m3) & Onsite & $2.6 E+00$ & $3.3 \mathrm{E}-01$ & 7.1 E-02 \\
\hline Continuous (s/m3) & Ottrsite & $2.3 \mathrm{E}-03$ & $2.3 \mathrm{E}-03$ & $2.8 \mathrm{E}-04$ \\
\hline Puif $(m-3)$ & Onsite & $7.9 \mathrm{E}-01$ & $9.9 \mathrm{E}-02$ & $2.1 \mathrm{E}-02$ \\
\hline Puff $(m-3)$ & Otfsite & $9.3 \mathrm{E}-06$ & $9.2 \mathrm{E}-06$ & $1.1 \mathrm{E}-06$ \\
\hline \multicolumn{5}{|c|}{$50 \% \mathrm{NaOH}$ releases } \\
\hline Continuous (s/L) & Onsite & $1.3 E+04$ & $1.0 E+03$ & $2.6 \mathrm{E}+02$ \\
\hline Continuous (s/L) & Offsite & $1.1 \mathrm{E}+01$ & $1.1 \mathrm{E}+01$ & $8.6 \mathrm{E}-01$ \\
\hline Puff $(L-1)$ & Onsite & $3.8 \mathrm{E}+03$ & $3.0 \mathrm{E}+02$ & $7.5 \mathrm{E}+01$ \\
\hline Puff (L-1) & Ottsite & $4.3 E-02$ & $4.3 E-02$ & $3.5 E-03$ \\
\hline \multicolumn{5}{|c|}{ All liquids and all solids continuous release } \\
\hline Al! liquids (s/L) & Onsite & $1.0 \mathrm{E}+04$ & $7.5 \mathrm{E}+02$ & $2.1 E+02$ \\
\hline All Liquids (s/L) & Offsite & $8.4 \mathrm{E}+00$ & $8.4 \mathrm{E}+00$ & $6.2 \mathrm{E}-01$ \\
\hline All solids (s/L) & Onsite & $5.1 E+04$ & $2.3 E+04$ & $1.2 \mathrm{E}+03$ \\
\hline All solids $(\mathrm{s} / \mathrm{L})$ & Offsite & $2.5 \mathrm{E}+02$ & $4.2 \mathrm{E}+0 \mathrm{l}$ & $1.9 \mathrm{E}+01$ \\
\hline
\end{tabular}


All liquids or solids puff release

\begin{tabular}{l|l|c|c|c|}
\hline All liquids (L-1) & Onsite & $2.9 \mathrm{E}+03$ & $2.2 \mathrm{E}+02$ & $6.0 \mathrm{E}+0 \mathrm{I}$ \\
\hline All liquids (L-1) & Offsite & $3.4 \mathrm{E}-02$ & $3.4 \mathrm{E}-02$ & $2.5 \mathrm{E}-03$ \\
\hline All solids (L-1) & Onsite & $1.5 \mathrm{E}+04$ & $6.6 \mathrm{E}+03$ & $3.6 \mathrm{E}+02$ \\
\hline All solids (L-1) & Offsite & $1.0 \mathrm{E}+00$ & $1.7 \mathrm{E}-01$ & $7.6 \mathrm{E}-02$ \\
\hline \multicolumn{5}{|c|}{ C-106 solids } \\
\hline Continuous (s/L) & Onsite & $5.9 \mathrm{E}+03$ & $1.1 \mathrm{E}+03$ & $3.0 \mathrm{E}+02$ \\
\hline Continuous (s/L) & Offsite & $1.0 \mathrm{E}+01$ & $5.0 \mathrm{E}+00$ & $9.2 \mathrm{E}-01$ \\
\hline Puff $(\mathrm{L}-1)$ & Onsite & $1.7 \mathrm{E}+03$ & $3.2 \mathrm{E}+02$ & $8.8 \mathrm{E}+0 \mathrm{I}$ \\
\hline Puff $(\mathrm{L}-1)$ & Offsite & $4.1 \mathrm{E}-02$ & $2.0 \mathrm{E}-02$ & $3.6 \mathrm{E}-03$ \\
\hline
\end{tabular}

The comparison to risk guidelines for chemical release consequences for a given accident scenario is determined using the following steps:

1. Determine the accident frequency range for the event.

2. Determine the type of material being released (i.e., SST solids or liquids. DST solids or liquids, headspace gases. $50 \% \mathrm{NaOH}$, all solids, all liquids, or the $\mathrm{C}-106$ composite).

3. Determine whether the release is a puff release or a continuous release. A release with a duration of less than 3.5 seconds can be treated as a putf release for maximum onsite individual evaluations. A release with a duration of less than 420 seconds can be treated as a putf release for maximum offsite individual evaluations. A puff release can be modeled as a i minute continuous release. 
Exposure Time:

Exposure time may be determined based on the following guidance taken from Craig $1995 \mathrm{a}$ "Exposure time: In practice, observed atmospheric concentrations of chemicals downwind of a suurst vary widely about the mean concentration measured over a period of time. Unless information to the contrary is available, published limit parameters or guidelines must be treated as ceiling values at the point of interest. For practical purposes. the peak 15 minute average concentration is treated as the instantaneous concentration. It is recommended that this concentration value be used tor comparison with the primary concentration guidelines."

For chemicals that are known to have dose dependent health effects rather than concentration dependent effects, a 1 hour average may be used. However if the chemicals are not all known ti he dose dependent, the 15 minute average should be used for releases of 15 minute to one hour. Tank waste, for instance, contains a mixture of dose dependent and concentration dependent chemicals. $t$ peak 15 minute average should be used tor the tank waste evaluations

Averaging over 15 minutes for a very short release duration and hence a very short exposure time (such as a puff release) is potentially nonconservative since some chemicals have ceiling timits. i.e. concentrations that should not be exceeded. There is some recent guidance from $\mathrm{Craig}$ (Craig 19950) that states:

"For practical reasons (e.g. limitations of instantaneous concentration monitoring for many chemicals) the peak 15 minute average value at the receptor point of interest is used except for those substances that may cause immediate irritation when exposure is short (e.g. hydrogen sultide. sulfur dioxide). In such cases if the release scenario gives rise to peak concentrations significantly higher than the peak 15-minute average concentration. then a shorter averaging time (not less than 1 minute) should be used." The chemicals involved in a release should be examined to determine if the chemicals involved cause immediate irritation. The chemicals should be assumed to cause immediate irritation unless it can be demonstrated otherwise.

A very short duration release (putf release) ot chemicals including corrosives and irritants can be modelled conservatively as a one minute continuous release. 
4. Determine the release quantity or release rate. For putf releases of solids or liquids, the number of liters released is required: for continuous releases of solids or liquids, the release rate is required. For puft releases of gases. the number of cubic meters released is required: tor continuous releases of gases, the release rate is required.

5. Multiply the release quantity or release rate determined in step 4 by the appropriate value from Table 3-8. The product is the sum of the concentrations divided by ERPG values. Values less than one indicate that the risk acceptance guidelines are met.

NOTE: The concentration of gases at the receptor is not linear with release rate or release amount. Determining acceptability by multiplying the values in Table 3-8 by the release rate or amount results in an approximation. The approximation is conservative because using the linear relationship over-predicts concentrations for releases larger than $1 \mathrm{~L}(0.26 \mathrm{gal})$ or $1 \mathrm{~L} / \mathrm{s}(0.26 \mathrm{gal} / \mathrm{s})$. The difference between linear scaling and the more exact method is negligible below release rates of about $5 \mathrm{~m} 3 / \mathrm{s}(180 \mathrm{ft} 3 / \mathrm{s})$ or release amounts of $5 \mathrm{~m} 3(180 \mathrm{tr})$. Because the nonlinear term in the gas equation is $1 /\left(1+V^{\prime} x \div / Q^{\prime}\right)$, this effect is only significant for the maximum onsite individual. For the maximum offsite individual. $V^{\prime} x \div / Q^{\prime}$ will be much smaller than one for any iredible release from the tanks. The largest offsite $\div / Q^{\prime}$ is $2.83+.88 \times 10-5 \mathrm{~s} / \mathrm{m} 3$ and all credible releases are much smaller than $105 \mathrm{~m} 3 / \mathrm{s}$.

Step 5 can also be written as the following tormulae:

- Liquid or solid continuous release:

Sum-of-fractions of acceprance limits $=$ [release rate $] \times$ [Table 3-8 continuous telease value]

- Liquid or solid putf release:

Sum-of-fractions of acceptance limits $=$ [release quantity $\times$ [Table 3-8 puff value]

Accident scenarios involving a release of both gases and solid or liquids should be treated by adding the sum of fractions for the gases and liquids or solids together. That is, the quantity of gas released should be multiplied by the sum of fraction and the product determined. The quantity of liquid or solid should multiplied by the appropriate sum of fraction. To meet risk acceptance criteria, the sum of these two products must be less than or equal to one.

The sum of fraction assumes that the-chemicals involved are being released with the same release fraction. If the accident scenario involves a significant preferential release of certain chemicals, a mure detailed analysis should be pertormed that includes the chemical dependent release fractions. 
Appendix $I B$

HEPA Filter Doses 
This appendix discusses the method used to calculate the amount of material on the filters in various tank farm facilities. To do this, Savino (1996) modeled $3.7 \times 10^{10} \mathrm{~Bq}$ ( $1 \mathrm{C}$ i) of gamma emitters in different filter configurations and calculated the contact doses. Depending on the source material, the ganma emitters are different. For example, single-shell solids uses ${ }^{90} \mathrm{Sr},{ }^{90} \mathrm{Y},{ }^{137} \mathrm{Cs}$ and ${ }^{154} \mathrm{Eu}$ for gamma emitters while double-shell 1 iquids uses predominantly ${ }^{137} \mathrm{Cs}$ (the other gamma emitters have much smaller concentrations). The spreadsheet tables give the relative amounts for each of the cases that were analyzed.

Different filter geometries were modeled. These include high efficiency particulate air filters and prefilters. After inputing the geometry and the loading, a dose rate (mSv/hr) was calculated.

High efficiency particulate air filters and prefilters have prespecified operating limits. These were used, along with the calculated dose rate to form a ratio of the operating limit to the calculated dose limit. This gives the fraction of the assumed waste volume that could be loaded on the filter and give the operating limit. The amount of material released from the a single bank of filters was calculated using one of the following schemes.

- The system is a standard active ventilation system with a prefilter, a first stage and second stage high efficiency particulate air filter. An additional amount, equal to another prefilter loading, was used to account for material that will come out of the ventilation duct work. That is, two prefilter volumes plus two high efficiency particulate air filter volumes will be used.

- The system is passively ventilated. The system is basically one high efficiency particulate filter sitting on a riser. There is not a prefilter and there is no ventilation ducting to speak of. That is, one high efficiency particulate air filter will be used.

- The system has two de-entrainers, a first stage and second stage high efficiency particulate air filter. To account for the loading in the de-entrainers and the material that will come out of the ventilation duct work, an additional volume equivalent to three high efficiency particulate filters will be used. That is a total of five times the loading for one high efficiency particulate filter will be used.

- The system consists of a prefilter, a low efficiency filter (treated as another prefilter), a first stage and second stage high efficiency particulate air filter. In addition, a volume equal to the prefilter will be used to account for material from the ventilation ducting. That is, a total of three prefilter volumes and two high efficiency particulate volumes will be used.

The spreadsheet pages also identify how many filter banks are running at the same time. A total amount of material released from the filters is found by multiplying by the appropriate release fraction. For a filter fire, the 
release fraction is $1 / 10,000$ of the volume is released. The volumes released are then be used to calculate radiological and toxicological doses.

The radiological consequences were calculated using the unit 1 iter doses found in Cowley (1996) and the methodology for calculating consequences is found in Van Keuren and Savino (1996). The unit liter doses are the radiation doses received per liter of tank waste. The doses are calculated using the pathways of submersion (direct radiation), inhalation, and 24-hour ingestion. Cowley (1996) provides the technical basis for the unit liter doses. Van Keuren and Savino (1996) states that the following equation is to be used for calculating the inhalation and submersion dose.

$$
E D E_{\text {inhalation }}=Q \frac{\chi}{Q^{\prime}} B_{r} U L D_{\text {inhalation }}
$$

where $Q$ is the volume of waste resuspended $(L), x / Q^{\prime}$ is the atmospheric dispersion coefficient $\left(\mathrm{s} / \mathrm{m}^{3}\right), B_{\text {is }}$ is the standard man breathing rate during light activity $\left(\mathrm{m}^{3} / \mathrm{s}\right)$, and the $U\left[D_{\text {inhalation }}\right.$ is the unit liter dose (Sv/L) due to inhalation and submersion.

Ingestion doses are calculated using the following equation.

$$
E D E_{\text {ingestion }}=Q \frac{X}{Q^{\prime}} U L D_{\text {ingestion }}
$$

where again, $Q$ is the volume of waste resuspended $(L), X / Q^{\prime}$ is the atmospheric dispersion coefficient $\left(\mathrm{s} / \mathrm{m}^{3}\right)$ and ULO ingestion is the unit liter dose $\left(\frac{5 v m^{3}}{\mathrm{~s} L}\right)$ due to 24-hour ingestion.

The toxicological consequences are calculated using the sum-of-fractions values and methodology found in Van Keuren (1996). For a release of solid or liquid toxic materiais, the peak concentratjon is of concern. For a continuous release the integrated $x / 0^{4}\left(\mathrm{~s} / \mathrm{m}^{3}\right)$ can be used since it is equivalent to the continuous plume $X / Q^{\prime}$. The following equation is used to calculate the peak concentration, $C\left(\mathrm{mg} / \mathrm{m}^{3}\right)$ for a continuous release of solid or liquid toxic material.

$$
C=Q^{\prime} \frac{x}{Q^{\prime}}
$$

where $Q^{\prime}$ is the toxic material release rate $(\mathrm{mg} / \mathrm{s})$ and $X / Q^{\prime}$ is the integrated atmospheric dispersion coefficient $\left(\mathrm{s} / \mathrm{m}^{3}\right)$. 
This method has been extended to include the multiple chemicals contained in the tank waste. To do this, a sum-of-fractions methodology has been applied. That is, on a per unit basis, the ratio of a chemicais concentration (calculated either at the $100 \mathrm{~m}$ receptor or the offsite receptor) is compared to the appropriate limit), this is done for all chemicals involved, then the ratios or fractions are summed. If the sum-offractions is less than or equal to 1 , the risk guidelines have been met. If the sum-of-fractions is greater than 1 , the risk guidelines have been exceeded. Thus, the above equation now becomes,

$$
T=Q^{\prime} S O F
$$

where $T$ is the measure of acceptance, $Q^{\prime}$ is the toxic material release rate $(L / S)$ and SOF is the sum-of-fractions of the risk guidelines ( $s / L$ ) for either the onsite or offsite receptor.

Cowley, W. L., 1996, Development of Radiological Concentration and Unit Liter Doses for Tank Waste Remediation System Final Safety Analysis Report Radiological Consequence Calculations, WHC-SD-WM-SARR-037, Rev. 0, Westinghouse Hanford Company, Richland, Washington.

Savino, A. V., 1996, MICROSHIELD Dose Rate Calculations for WEPA Filters and. Prefilters, WHC-SD-WM-CN-033, Rev. 0, Westinghouse Hanford Company, Richiand, Washington.

Van Keuren, J. C., and A. V. Savino, 1996, Tank Waste Compositions and Atmospheric Dispersion Coefficients for use in Safety Analysis Consequence Assessments, WHC-SD-WM-SARR-016, Rev. 2, Westinghouse Hanford Company, Richl and, Washington.

Van Keuren, J. C., 1996, Toxic Chemical Considerations for Tank Farm Releases, WHC-SD-WM-SARR-011, Rev. 2, Westinghouse Hanford Company, Richland, Washington. 


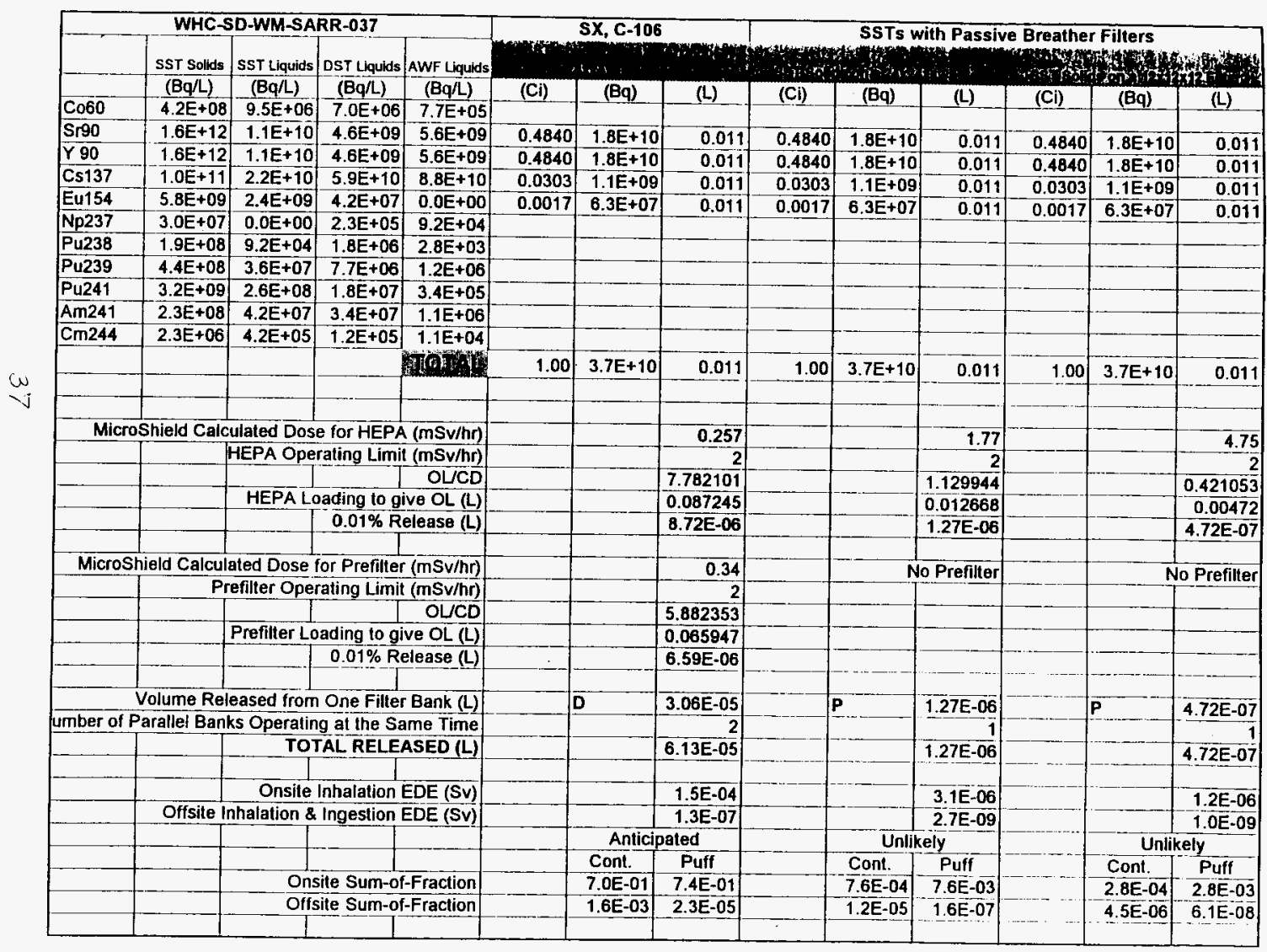




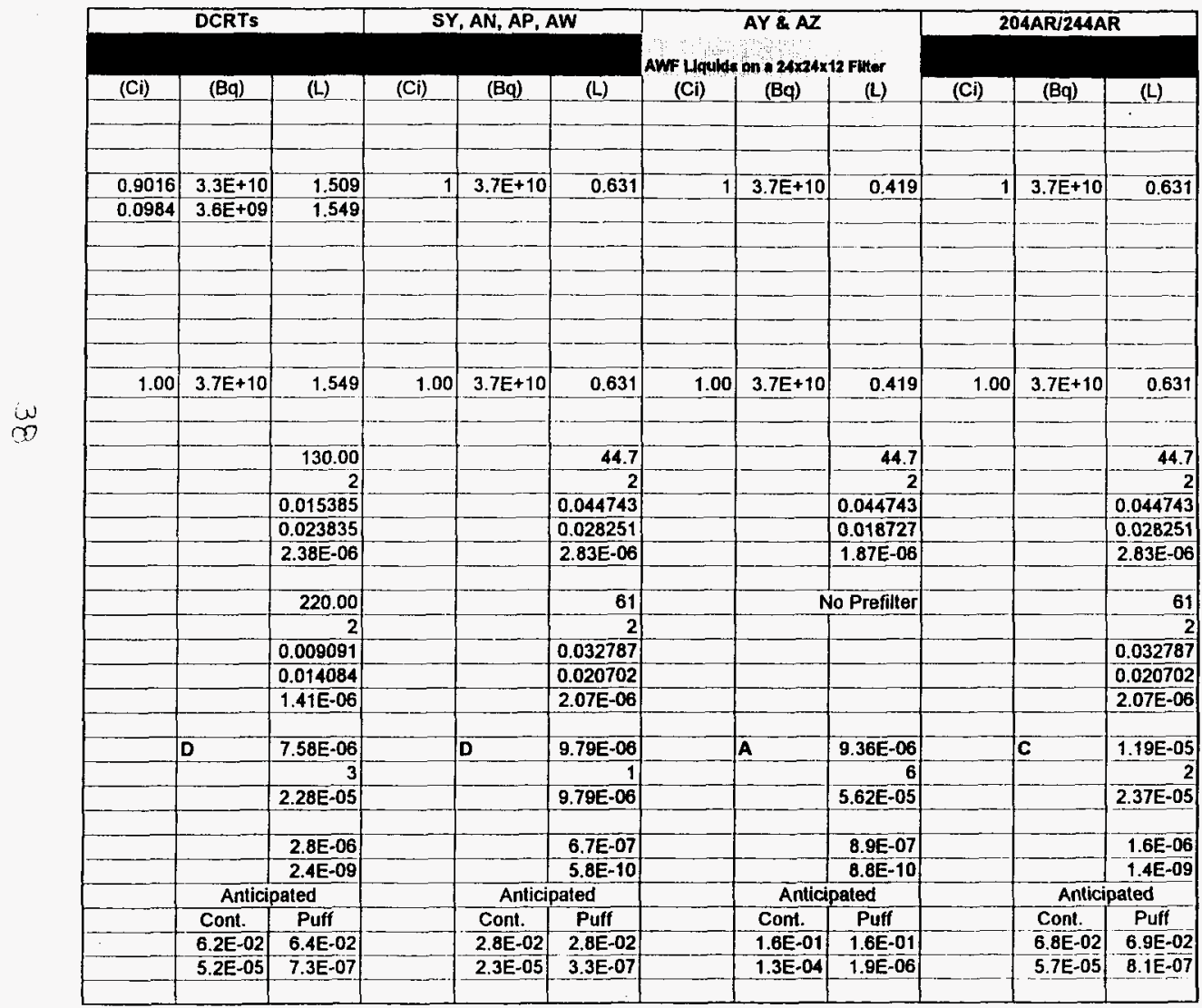




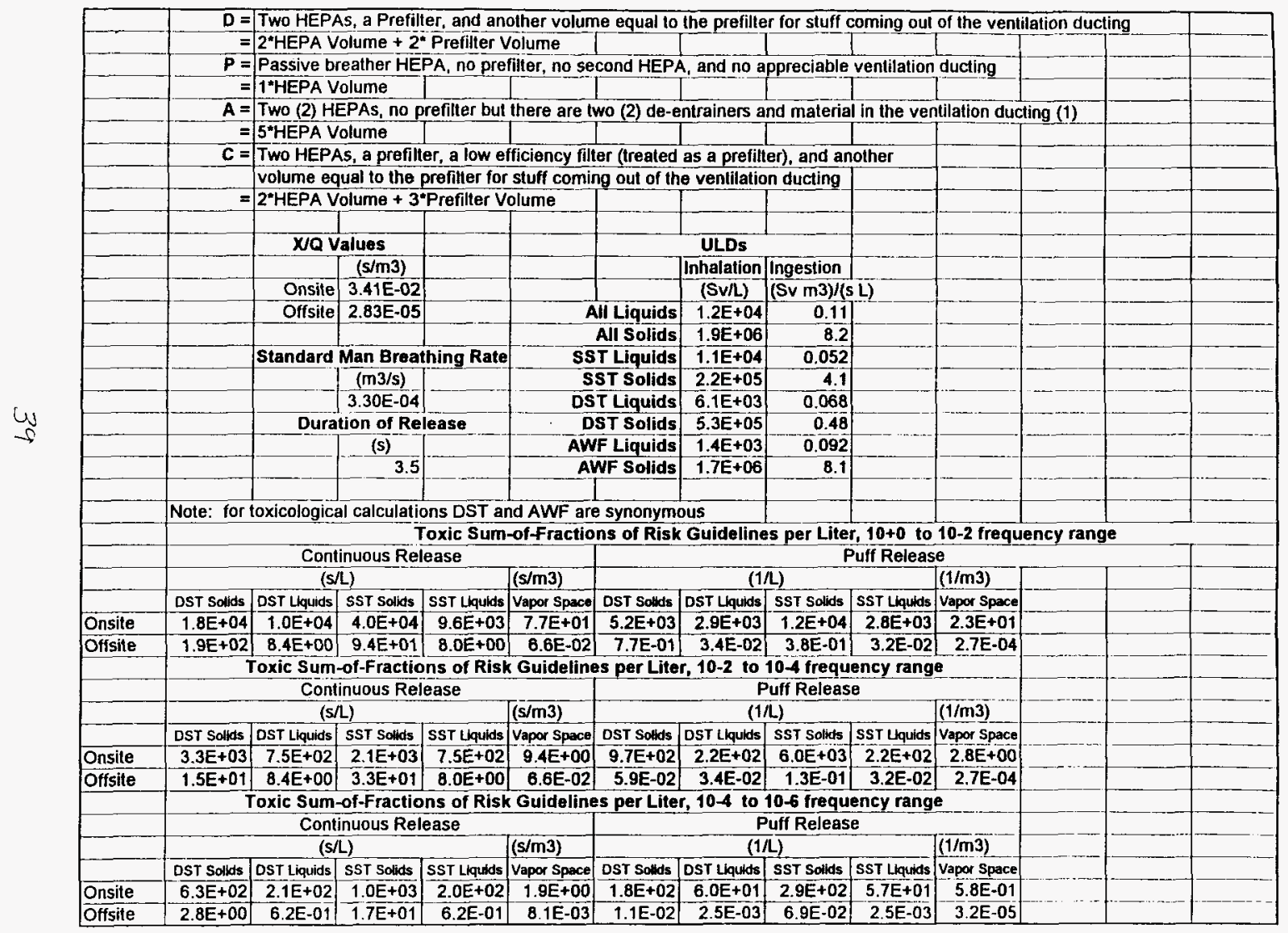


Table 3.4.1-5. Unit Liter Doses for Inhalation and Ingestion.*

\begin{tabular}{|l|c|c|}
\hline \multicolumn{1}{|c|}{ Composite } & $\begin{array}{c}\text { Inhalation ULD } \\
(\mathrm{SV} / \mathrm{L})\end{array}$ & $\begin{array}{c}\text { Ingestion ULD* } \\
\left(\mathrm{Sv}-\mathrm{m}^{3} / \mathrm{s}-\mathrm{L}\right)\end{array}$ \\
\hline Single-ghel1 tank 1iquids & $1.1 \mathrm{E}+04$ & 0.052 \\
\hline single-shell tank solids & $2.2 \mathrm{E}+05$ & 4.1 \\
\hline Double-shell tank liquids & $6.1 \mathrm{E}+03$ & 0.068 \\
\hline Double-shell tank solids & $5.3 \mathrm{E}+05$ & 0.48 \\
\hline Aging waste fac1lity liquids & $1.4 \mathrm{E}+03$ & 0.092 \\
\hline Aging waste fac1l1ty solids & $1.7 \mathrm{E}+06$ & 8.1 \\
\hline
\end{tabular}


Table 4. Centerline Atmospheric Dispersion Coefficients for 200-Area Tank Farm Acute Release to $100-\mathrm{m}$ Onsite Receptor Located in Worst Sector.

\begin{tabular}{|l|c|c|c|}
\hline \multicolumn{1}{|c|}{ Meteorological condition } & $\begin{array}{c}\text { Integrated } \div / \mathrm{Q}^{\prime} \\
(\mathrm{s} / \mathrm{m} 3)\end{array}$ & $\begin{array}{c}\text { Integrated } \div / \mathrm{Q}^{\prime} \\
(\mathrm{s} / \mathrm{m} 3) \text { with } \mathrm{PMa}\end{array}$ & $\begin{array}{c}\text { Maximum puft } \\
+/ \mathrm{Q}(1 / \mathrm{m} 3)\end{array}$ \\
\hline 99.5 percentile & $3.41 \mathrm{E}-02$ & $1.13 \mathrm{E}-02$ & $9.85 \mathrm{E}-03$ \\
(bounding) & E $100 \mathrm{~m}$ & ESE $100 \mathrm{~m}$ & E $100 \mathrm{~m}$ \\
\hline Annual Average & $1.20 \mathrm{E}-02$ & $3.80 \mathrm{E}-03$ & $\mathrm{NA}$ \\
& $\mathrm{N} 100 \mathrm{~m}$ & $\mathrm{~N} 100 \mathrm{~m}$ & \\
\hline 50 percentile & $5.33 \mathrm{E}-03$ & $2.27 \mathrm{E}-03$ & $9.48 \mathrm{E}-04$ \\
& $\mathrm{~N} 100 \mathrm{~m}$ & $\mathrm{~N} 100 \mathrm{~m}$ & $\mathrm{E} 100 \mathrm{~m}$ \\
\hline
\end{tabular}

aNRC Regulatory Guide 1.145 (NRC 1982) plume meander correction applied.

Table 5. Centerline Atmospheric Dispersion Coefficients for 200-Area Tank Farm Acute Release to Site Boundary Receptor Located in Worst Sector.

\begin{tabular}{|l|c|c|c|}
\hline \multicolumn{1}{|c|}{ Meteorological condition } & $\begin{array}{c}\text { Integrated } \div / \mathrm{Q}^{\prime} \\
(\mathrm{s} / \mathrm{m} 3)\end{array}$ & $\begin{array}{c}\text { Integrated } \div / \mathrm{Q}^{\prime} \\
(\mathrm{s} / \mathrm{m} 3) \text { with PMa }\end{array}$ & $\begin{array}{c}\text { Maximum puti } \\
\div / \mathrm{Q}(1 / \mathrm{m} 3)\end{array}$ \\
\hline 99.5 Percentile & $2.83 \mathrm{E}-05$ & $2.12 \mathrm{E}-05$ & $1.14 \mathrm{E}-07$ \\
(bounding) & $N 8.760 \mathrm{~m}$ & $\mathrm{~N} 8,760 \mathrm{~m}$ & NNW $8.690 \mathrm{~m}$ \\
\hline Annual average & $1.05 \mathrm{E}-05$ & $7.92 \mathrm{E}-06$ & NA \\
& $N 8.760 \mathrm{~m}$ & $\mathrm{~N} 8,760 \mathrm{~m}$ & \\
\hline 50 percentile & $4.43 \mathrm{E}-06$ & $3.79 \mathrm{E}-06$ & $1.02 \mathrm{E}-08$ \\
& $\mathrm{N8.760 \textrm {m }}$ & $\mathrm{N} \mathrm{8,760 \textrm {m }}$ & $\mathrm{N} 8.760 \mathrm{~m}$ \\
\hline
\end{tabular}

aNRC Regulatory Guide 1.145 (NRC 1982) plume meander correction applied.

Table 6. Population Weighted Atmospheric Dispersion Coefficients for 200-Area Tank Farm Acute Release to 50-Mile Population Located in Worst Sector.

\begin{tabular}{|l|c|}
\hline \multicolumn{1}{|c|}{ Meteorological condition } & $\begin{array}{c}\text { Integrated } \div / Q^{\prime} \\
\text { (person-s/m3) }\end{array}$ \\
\hline $\begin{array}{l}99.5 \text { Percentile } \\
\text { (bounding) }\end{array}$ & $\begin{array}{c}4.86 \mathrm{E}-02 \\
\text { SE pop }=114,734\end{array}$ \\
\hline Annual average & $1.25 \mathrm{E}-02$ \\
& $\mathrm{SE} \mathrm{pop}=114734$ \\
\hline 50 Percentile & $6.05 \mathrm{E}-03$ \\
& $\mathrm{SE}$ pop $=114,734$ \\
\hline
\end{tabular}


Table 7. Centerline Atmospheric Dispersion Coefficients for 200-Area Tank Farm Acute Release to Onsite Receptor Located in Worst Sector tor a $46 \mathrm{~m}$ (150 ft) Stack Release.

\begin{tabular}{|l|c|c|}
\hline \multicolumn{1}{|c|}{ Meteorological condition } & $\begin{array}{c}\text { Integrated } \div / \mathrm{Q}^{\prime} \\
(\mathrm{s} / \mathrm{m} 3)\end{array}$ & $\begin{array}{c}\text { Maximum puff } \div / \mathrm{Q} \\
(\mathrm{I} / \mathrm{m} 3)\end{array}$ \\
\hline $\begin{array}{l}99.5 \text { Percentile } \\
\text { (bounding) }\end{array}$ & $\begin{array}{c}6.55 \mathrm{E}-05 \\
\text { W } 260 \mathrm{~m}\end{array}$ & $\begin{array}{c}6.47 \mathrm{E}-7 \\
\mathrm{~W} 210 \mathrm{~m}\end{array}$ \\
\hline Annual Average & $\begin{array}{c}1.76 \mathrm{E}-05 \\
\text { WSW } 270 \mathrm{~m}\end{array}$ & NA \\
\hline 50 Percentile & $\begin{array}{c}1.26 \mathrm{E}-05 \\
\text { WSW } 440 \mathrm{~m}\end{array}$ & $\begin{array}{c}1.41 \mathrm{E}-07 \\
\text { WSW } 490 \mathrm{~m}\end{array}$ \\
\hline
\end{tabular}

Table 8. Centerline Atmospheric Dispersion Coefficients tor 200-Area

Tank Farm Acute Release to Site Boundary Receptor Located in Worst Sector for a $46 \mathrm{~m}$ (150 tit) Stack Release.

\begin{tabular}{l|c|c|}
\hline \multicolumn{1}{|c|}{ Meteorological Condition } & Integrated $\div / \mathrm{Q}^{\prime}(\mathrm{s} / \mathrm{m} 3)$ & $\begin{array}{c}\text { Maximum Puff } \div \mathrm{Q} \\
(1 / \mathrm{m} 3)\end{array}$ \\
\hline 99.5 Percentile & $1.78 \mathrm{E}-05$ & $3.10 \mathrm{E}-08$ \\
(bounding) & $\mathrm{N} 8.760 \mathrm{~m}$ & $\mathrm{NNW} 8.690 \mathrm{~m}$ \\
\hline Annual average & $5.26 \mathrm{E}-06$ & $\mathrm{NA}$ \\
& $\mathrm{N} 8,760 \mathrm{~m}$ & $8.31 \mathrm{E}-09$ \\
\hline S0 Percentile & $2.36 \mathrm{E}-06$ & $\mathrm{~N} 8.760 \mathrm{~m}$ \\
& $\mathrm{~N} 8.760 \mathrm{~m}$ & \\
\hline
\end{tabular}

Table 9. Chronic Annual Average Atmospheric Dispersion Coefficients for 200-Area Tank Farm for Onsite and Site Boundary Receptors.

\begin{tabular}{|l|c|c|}
\hline \multicolumn{1}{|c|}{ Meteorological condition } & $\begin{array}{c}\text { Onsite } \\
\text { integrated } \div / Q^{\prime} \\
(\mathrm{s} / \mathrm{m} 3)\end{array}$ & $\begin{array}{c}\text { Site } \\
\text { boundary } \\
\text { integrated } \div / \mathrm{Q}^{\prime}(\mathrm{s} / \mathrm{m} 3)\end{array}$ \\
\hline $\begin{array}{l}\text { Chronic annual average for } \\
\text { ground level releases }\end{array}$ & $4.03 \mathrm{E}-04$ & $1.24 \mathrm{E}-07$ \\
\hline Chronic annual average for & ESE $100 \mathrm{~m}$ & E $12.630 \mathrm{~m}$ \\
$46 \mathrm{~m}(150 \mathrm{ft})$ stack releases & $9.45 \mathrm{E}-07$ & $6.81 \mathrm{E}-08$ \\
$\mathrm{~S} 250 \mathrm{~m}$ & $\mathrm{E} 12.630 \mathrm{~m}$ \\
\hline
\end{tabular}


Tracking \# MKG-Chaoter 3-01

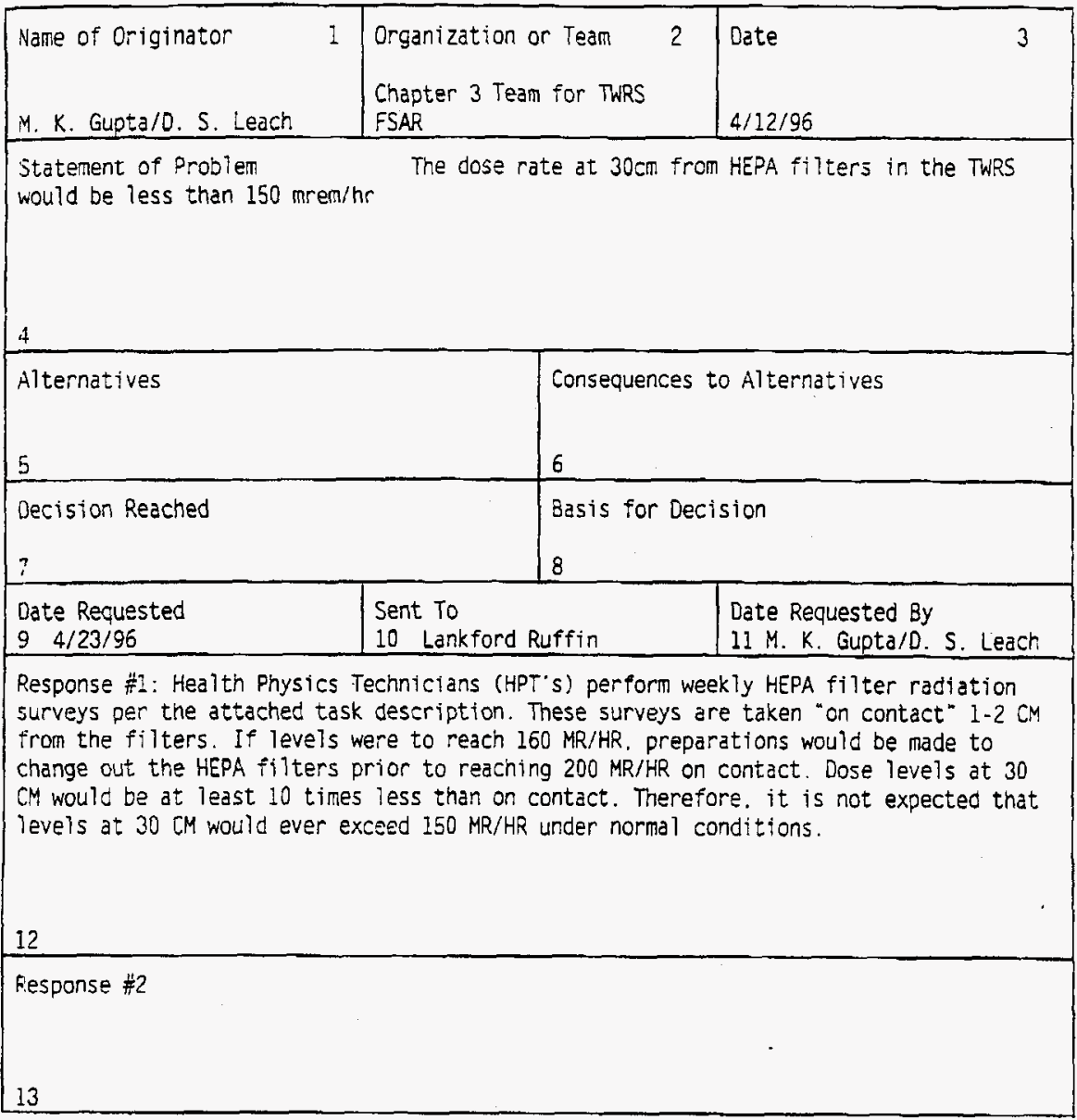




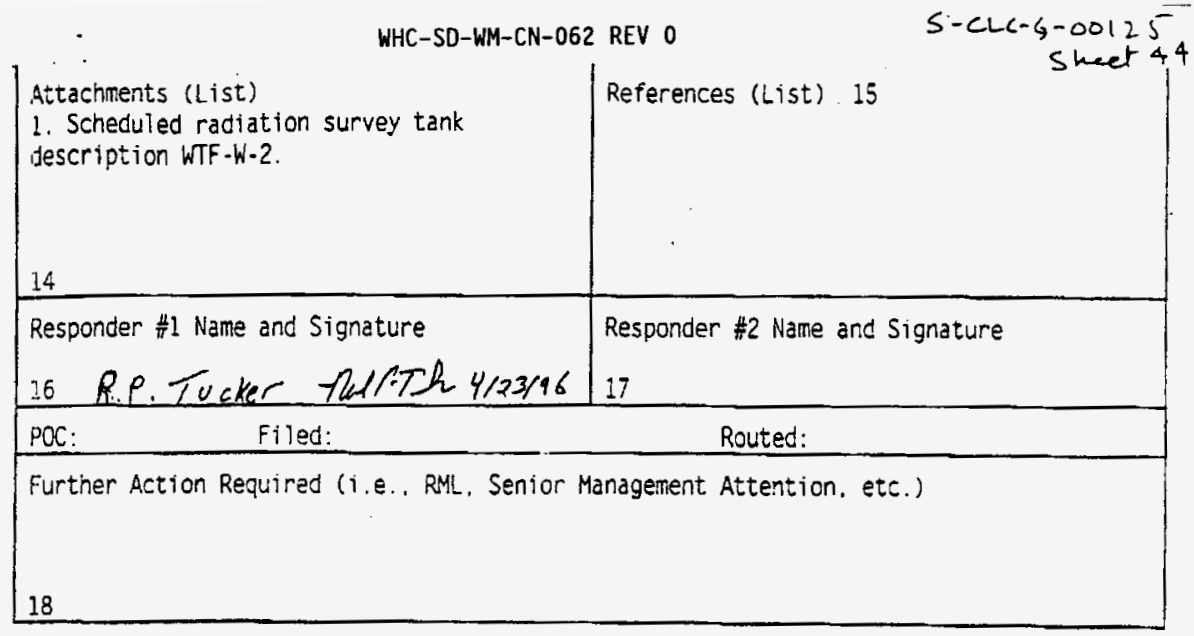

March 7. 1996

Page 5

Rev. 0

44 


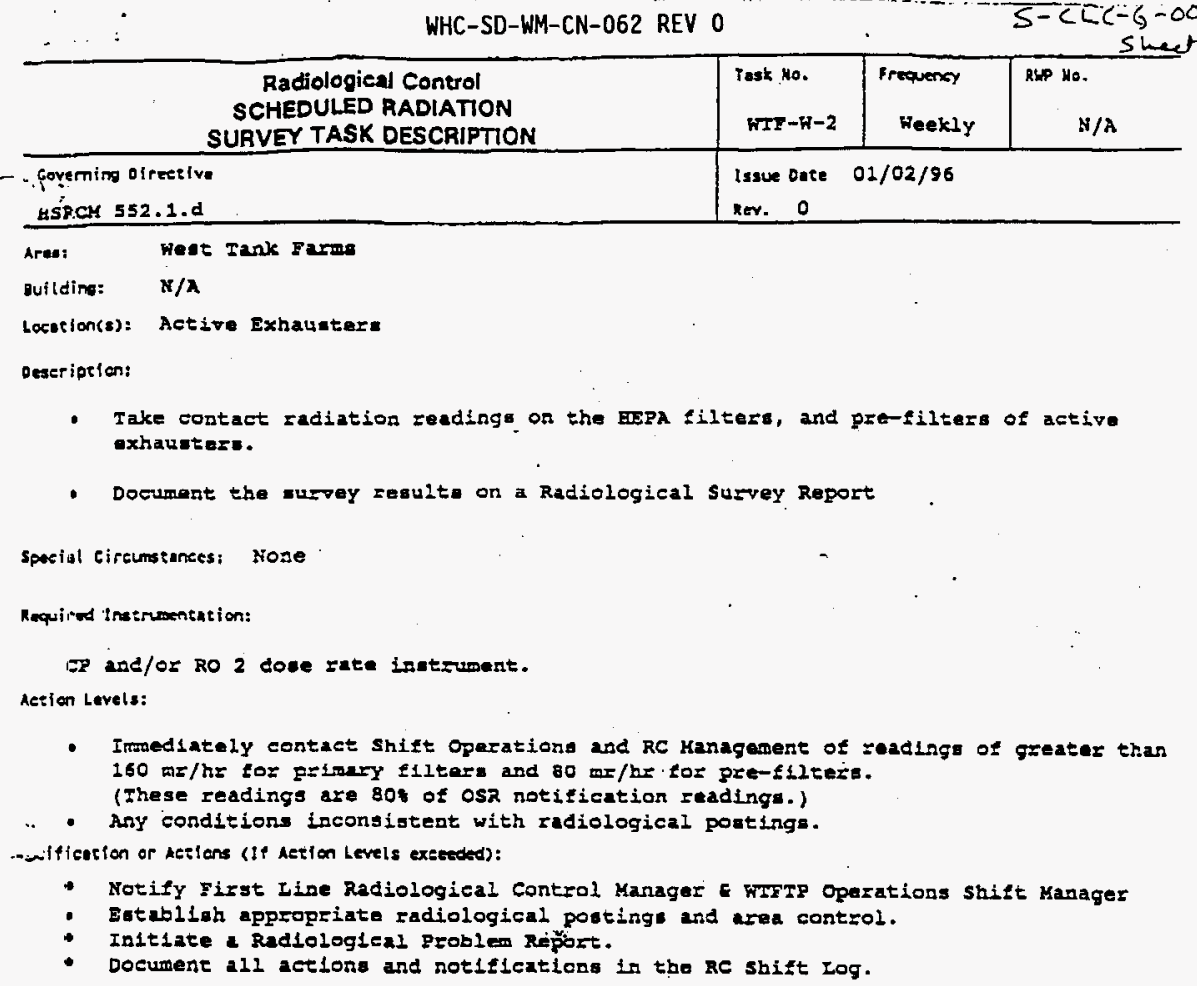

- Take contact radiation readings on the EDPA filters, and pre-filters of active exhaunters.

- Documant the murvey resulte on a Radiological survey Report .

Spacial Cireumstaness: Hone

Requird Insementation:

GP and/Or RO 2 done rate inntzugent.

Aerien Levels:

- Irmediately contact Shift opecationd and RC Hanagenent of zeadinga of greater than

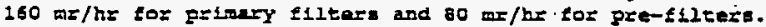

(These readings are 80 of OSR notification readings.)

.. Any conditions inconsistent with radiological poatings.

-nificerion or Aczions (ti ketion Levels execeded):

- Notify First Iine Radiologieal Contfol Kanager c Hrrsp Operations shift Kanager

- Establiah appropriate radiologieal posting and area control.

- Initlate a Radiologleal Pzoblem Repót.

- Document 211 aetlona and notiflextions in the Re shift rog.
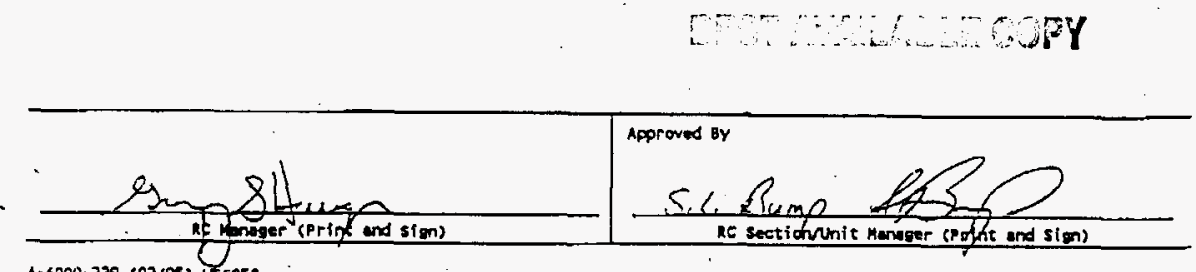
A.6000)-229 (02/95) Wfo50

$$
45
$$




\begin{tabular}{|c|c|c|c|c|c|}
\hline \multicolumn{6}{|c|}{ DISTRIBUTION SHEET } \\
\hline To & \multirow{2}{*}{\multicolumn{2}{|c|}{$\begin{array}{l}\text { From } \\
\text { G. W. Ryan }\end{array}$}} & & \multicolumn{2}{|c|}{ Page 1 of 1} \\
\hline Distribution & & & & \multicolumn{2}{|c|}{ Date $8 / 9 / 96$} \\
\hline \multirow{2}{*}{\multicolumn{3}{|c|}{$\begin{array}{l}\text { Project Title/Work Order } \\
\text { HEPA Filter Fire (and Subsequent Unfiltered Release) }\end{array}$}} & & \multirow{2}{*}{\multicolumn{2}{|c|}{$\begin{array}{ll}\text { EDT No. } & 614551 \\
\text { ECN No. } & \text { N/A }\end{array}$}} \\
\hline & & & & & \\
\hline Name & MSIN & $\begin{array}{c}\text { Text } \\
\text { With All } \\
\text { Attach. }\end{array}$ & Text Only & $\begin{array}{l}\text { Attach./ } \\
\text { Appendix } \\
\text { Only }\end{array}$ & $\begin{array}{l}\text { EDT/ECN } \\
\text { Only }\end{array}$ \\
\hline $\begin{array}{l}\text { E. R. Bruschi } \\
\text { C. Carro } \\
\text { D. S. Leach } \\
\text { TWRS S \& L Project Files (6) } \\
\text { G. W. Ryan (3) } \\
\text { Central Files (Original + 1) }\end{array}$ & $\begin{array}{l}A 2-34 \\
A 2-34 \\
A 3-34 \\
A 2-26 \\
A 3-37 \\
A 3-88\end{array}$ & $\begin{array}{l}x \\
x \\
x \\
x \\
X \\
x\end{array}$ & & & \\
\hline
\end{tabular}

